Lanckriet, S., Tesfay Araya, Cornelis, W., Verfaillie, E., Poesen, J., Govaerts, B., Bauer, H., Deckers, S., Mitiku Haile, Nyssen, J., 2012. Impacts of conservation agriculture on runoff and soil loss under changing climate conditions in May Zeg-zeg (Ethiopia). Journal of Hydrology, 475: 336-349.

\title{
Impact of conservation agriculture on catchment runoff and soil loss under changing climate conditions in May Zeg-zeg (Ethiopia)
}

Sil Lanckriet ${ }^{1}$, Tesfay Araya $^{2,3}$, Wim Cornelis ${ }^{3}$, Els Verfaillie ${ }^{1}$, Jean Poesen ${ }^{4}$, Bram Govaerts ${ }^{5}$, Hans Bauer ${ }^{4}$, Jozef Deckers ${ }^{4}$, Mitiku Haile ${ }^{6}$, Jan Nyssen ${ }^{1, *}$

1 Ghent University, Department of Geography, B-9000 Gent, Belgium

2 Mekelle University, Department of Crop and Horticultural Science, Mekelle, Ethiopia.

3 Ghent University, Department of Soil Management, B-9000 Gent, Belgium

4 KULeuven, Department of Earth and Environmental Sciences, B-3001 Heverlee, Belgium

5 International Maize and Wheat Improvement Centre (CIMMYT), México D.F. 06600,

México

6 Mekelle University, Department of Land Resources Management and Environmental Protection, Mekelle, Ethiopia.

* Corresponding author. Email: jan.nyssen@ugent.be; Tel. ++32 92644623 ; Fax ++32 9 2644985 ; Ghent University, Department of Geography, Krijgslaan 281 (S8), B-9000 Gent, Belgium

\begin{abstract}
This study evaluates the practice of conservation agriculture (CA) in the May Zeg-zeg catchment (MZZ; 187 ha) in the North Ethiopian Highlands as a soil management technique for reducing soil loss and runoff, and assesses the consequences of future large-scale implementation on soil and hydrology at catchment-level. The study of such practice is important especially under conditions of climate change, since EdGCM (Educational Global Climate Model) simulation predicts by 2040 an increase in precipitation by more than 100 $\mathrm{mm} \mathrm{yr}^{-1}$ in the study area. Firstly, field-saturated infiltration rates, together with soil texture and soil organic carbon contents, were measured. The relation with local topography allows to generate a pedotransfer function for field-saturated infiltration rate, and spatial interpolation with Linear Regression Mapping was used to map field-saturated infiltration rates optimally within the catchment. Secondly, on several farmlands, CA was checked against Plain Tillage (PT) for values of field-saturated infiltration rates, soil organic carbon, runoff and soil loss. Results show no significant differences for infiltration rates but significant differences for runoff and soil loss (as measured in the period 2005-2011). Runoff coefficients were $30.4 \%$ for PT and $18.8 \%$ for CA; soil losses were $35.4 \mathrm{t} \mathrm{ha}^{-1} \mathrm{yr}^{-1}$ for PT and $14.4 \mathrm{t} \mathrm{ha}^{-1} \mathrm{yr}^{-1}$ for CA. Thirdly, all collected information was used to predict future catchment hydrological response for full-implementation of CA under the predicted wetter climate (simulation with EdGCM). Curve Numbers for farmlands with CA were calculated. An area-weighted Curve Number allows the simulation of the 2011 rainy season runoff, predicting a total runoff depth of 23.5 $\mathrm{mm}$ under CA and $27.9 \mathrm{~mm}$ under PT. Furthermore, the Revised Universal Soil Loss Equation management factor $\mathrm{P}$ was calibrated for CA. Results also show the important
\end{abstract}


influence of increased surface roughness on water ponding, modeled with a hydrologic conservation balance. By coupling this model with the infiltration rate map, a 'ponding map' of the catchment was established. Finally, a sediment budget for a full future implementation scenario of CA has been estimated, predicting a large impact of CA on sheet and rill erosion rates, since total soil loss due to sheet and rill erosion in cropland would become $581 \mathrm{t} \mathrm{yr}^{-1}$ instead of $1109{\mathrm{t} \mathrm{yr}^{-1}}^{2}$, if CA would be practiced in MZZ. Simulation of several policy scenarios shows that especially under a future wetter North-East-African climate, CA would be a beneficial alternative for the current plain tillage, as it will increase infiltration and keep runoff coefficients under control.

Key words: Curve Number; Infiltration; Organic carbon; Permanent bed; Ponding; Water conservation

\section{Introduction}

Agricultural production in the North-Ethiopian Highlands is highly threatened by land degradation and desertification (Nyssen et al., 2004, and references therein). High rainfall erosivity (Nyssen et al., 2005), economic poverty, and a long-term human impact on the natural environment (Berakhi et al., 1998) exert a strong pressure on economic production capacity of the agricultural lands. Therefore, soil and water conservation projects are widely implemented, and especially in the catchment of May Zeg-zeg (MZZ; 187 ha) the effects of integrated catchment management are well studied (Nyssen et al., 2009a). Since 2004, stone bunds were built in the whole MZZ catchment, vegetation was allowed to re-grow on steep slopes and other marginal land, stubble grazing was abandoned, and check dams were built in gullies. From 2000 to 2006, a combination of decreased soil loss (from $14.3 \mathrm{t} \mathrm{ha}^{-1} \mathrm{yr}^{-1}$ to $9.0 \mathrm{t}$ $\mathrm{ha}^{-1} \mathrm{yr}^{-1}$ ) and increased sediment deposition (from 5.8 to $7.1 \mathrm{t} \mathrm{ha}^{-1} \mathrm{yr}^{-1}$ ) has led to a strongly decreased sediment yield (from 8.5 to $1.9 \mathrm{t} \mathrm{ha}^{-1} \mathrm{yr}^{-1}$ ) and sediment delivery ratio (from 0.6 to 0.21) (Nyssen et al., 2009a).

Conservation Agriculture (CA) has been introduced worldwide to curb the reduction in soil fertility and to reduce runoff and topsoil loss. CA allows in situ moisture conservation, thereby increasing crop yield. However, comparison of CA and conventional tillage practices over different time periods and places have not been consistent across soils, climate, tillage methods, crop type and experiments. In 2005, the CA technique was introduced on several farmlands in the MZZ catchment, since it would allow the improvement of soil quality and crop yield, while reducing soil loss and runoff (Tesfay Araya et al., 2011). The CA-technique applied in the North Ethiopian Highlands is named derdero+ (Nyssen et al., 2011). This technique consists of (i) the creation of beds and furrows after seed broadcasting, in order to increase water storage (derdero); (ii) the application of zero tillage (beds are never ploughed, the furrows are refreshed only once a year at sowing); (iii) leaving 30\% standing stubble, in order to increase soil organic carbon and improve soil structure; and (iv) using herbicide to control weeds (Tesfay Araya et al., 2012). In order to increase adoption by local farmers, plowing is done with the traditional ard plough or maresha (Fig. 1).

$* * *$ Figure 1 approximately here $* * *$

The aim of this study was to forecast the future soil-water behavior in the MZZ catchment if CA would be fully implemented within the entire catchment. Firstly, to account for, the impact of global warming (IPCC scenario A1FI) under future conditions, a climate simulation was performed in EdGCM (Educational Global Climate Model) (Chandler et al., 2005). 
Secondly, to understand current soil-water relations in the study area, field-saturated infiltration rates, soil texture and soil organic carbon contents, were quantified with single ring with constant head infiltrometer, sieving and X-ray sedigraphy, and Walkley-Black procedures respectively. Combination of the above with topography and using multiple linear regression yielded a pedotransfer function to predict field-saturated infiltration rates, which were mapped for the entire catchment using interpolation techniques.

Thirdly, CA was compared to plain tillage (PT) in an experimental setting for several biophysical variables. The variables incorporated were field-saturated infiltration rates (measured with single ring with constant head infiltrometer), runoff and soil loss (measured on several experimental plots) and soil organic carbon (quantified with Walkley-Black procedure).

Finally, to know future soil-water behavior under conditions of climate change, soil-water behavior was modeled using RUSLE model, Curve Number model and Ponding model, which were calibrated and validated with all information collected. Depending on six policy scenarios (climate change $\mathrm{x}$ land management), the models were used to predict future soil loss, runoff and sediment budget. The study of the different policy scenario projections allowed the evaluation of land management effectiveness with and without CA.

\section{Methods and materials}

\subsection{Experimental setup, study area and climate}

The scientific setup is a combination of empirical measurements and calibration of existing models that were validated for the study area (Fig. 2). Statistical analyses (ANOVA, TukeyHSD test, regression) were performed with packages $\mathrm{R}^{\circledR}$ and $\mathrm{S}+{ }^{\circledR}$. Spatial analysis and mapping was performed with GIS ( $\mathrm{R}^{\circledR}$ and ArcGIS ${ }^{\circledR}$ ).

$* * *$ Figure 2 approximately here $* * *$

Field work was executed between July and September 2011. within the catchment of May-

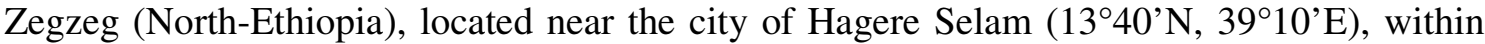
the Dogu'a Tembien district of Tigray (Fig. 3). The catchment was chosen for the study, since it's morphostructure is, according to (Nyssen et al., 2008), quite representative for the Northern Ethiopian Highlands. May-Zegzeg is drained by the Atbara-Takazze river system, directing the water towards the Nile.

$* * *$ Figure 3 approximately here $* * *$

The tabular geomorphology of the study area is strongly influenced by the subhorizontal morphostructure of the layers (Merla et al., 1979). The lower parts of the catchment (Argaka) consist of Mesozoic sedimentary Antalo limestone. A layer of hard Amba Aradam sandstone, visible in the landscape as a steep cliff of red rock, is situated upon these strata. On top of the sandstone, subhorizontal Tertiary basalt lavas are present in the Zenako area (Nyssen et al., 2008). After Miocene and Pliocene-Pleistocene tectonic uplift, Early Holocene weathering and soil genesis (Nyssen et al., 2004) resulted in the occurrence of Vertisols, Vertic Cambisols, Cumulic Regosols, Calcaric Regosols and Phaeozems (Vanmaercke et al., 2010). In Zenako, these are ordered in the following catena (from top to bottom): Leptosols (7.3\% of the catchment area; deeply eroded Luvisols) - Regosols (49.8\% of the catchment area) Cambisols (17.1\% of the catchment area) and walka Vertisols (20.4\% of the catchment area) 
(Nyssen et al., 2008). In Argaka, most soils are Regosols, although the spatial soil pattern is more complex.

Most rainfall occurs in the period June-September (kiremt rain) during localized but intense convective storm events in the afternoon (Nyssen et al., 2005), which is due to the seasonal movement of the intertropical convergence zone (Goebel and Odenyo, 1984) and due to enhanced westerlies, caused by the stronger north-east pressure gradient between the Guinea anticyclone and the Arab monsoon trough (Segele et al., 2009). Some rain can be observed in April-May (belg or azmera), due to the early formation of the meridional branch of the Somali jet along the East African coast (Riddle and Cook, 2008), and due to a high-amplitude Madden-Julian Oscillation (Williams and Funk, 2011). Yet, yearly rainfall is very variable (Fig. 4), since high yearly rainfall is also depending on a strong Somali low-level jet, a strong tropical easterly jet, and the occurrence of La Niña events (Segele et al., 2009). At local scale, rainy cloud development is highly dependent on topographic slope (Nyssen et al., 2005).

$* * *$ Figure 4 approximately here $* * *$

In order to assess effects of climate change, a simulation with EdGCM (Chandler et al., 2005) was used to show changing precipitation under $\mathrm{CO}_{2}$ trend of A1FI IPCC scenario of a future world with emphasis on fossil-fuel intensive sources. The model numerically solves the physical conservation equations for energy, mass, momentum and moisture as well as the equation of state (Hansen et al., 1983). Input is set with a mixed layer - deep diffusion ocean model. The model seems to simulate the regional climate quite well, since average precipitation for 1972-1984 was measured at $770 \mathrm{~mm} \mathrm{yr}^{-1}$ (Fig. 4), and simulated rainfall for that period was $365 * 2.32 \mathrm{~mm} \mathrm{day}^{-1}=848 \mathrm{~mm} \mathrm{yr}^{-1}$ (Fig. 5, left), thus indicating a light overestimation. For the period 2041-2050, the IPCC A1FI scenario predicts an increase of precipitation $\left(365 * 2.67 \mathrm{~mm} \mathrm{day}^{-1}=973 \mathrm{~mm} \mathrm{yr}^{-1}\right)$. This is in accordance with most climate models, predicting a wetter East-African climate under conditions of global warming (Williams and Funk, 2011). However, according to Williams and Funk (2011), a warm pool over the Indian Ocean, and the associated movement of diabatic heated air by Walker northeastern trade winds towards eastern Africa, would suppress azmera rains. However, given the total increase in precipitation, one may reasonably expect strongly increased rainfall intensities.

$* * *$ Figure 5 approximately here $* * *$

\subsection{Rainfall, runoff and soil loss at the experimental plots}

Located within farmers' fields in Zenako (upper catchment of MZZ), six rectangular plots (size $5 \mathrm{~m} \mathrm{x} 14 \mathrm{~m}$, soil type Vertic Cambisol, slope gradients of 6.5\%, and high stone cover) are monitored since 2005 (Tesfay Araya et al., 2012). Two tillage practices were applied with ard plough (maresha): plain tillage (three tillage operations, harvest without leaving residues, and weeding by hand), and derdero+. Crops sown (by broadcasting) for all years were sequentially: wheat, grass pea, wheat, hanfets (wheat and barley sown together), grass pea and wheat. Fertilizer (di-ammonium phosphate for all crops and urea for all crops except grass pea) was applied at $100 \mathrm{~kg} \mathrm{ha}^{-1}$. From $2007 \mathrm{on}$, non-selective herbicide glyphosate (N(phosphonomethyl) glycin), sprayed at $2 \mathrm{~L} \mathrm{ha}^{-1}$ three to four days before planting, replaced weeding by hand (Tesfay Araya et al., 2012).

At the experimental site, a rain gauge is installed and daily rain was monitored every morning at 8:00 AM. Runoff and soil loss were also measured every morning at 8:00 AM in 
downslope collector trenches lined with a geomembrane (dimensions $4.5 \mathrm{~m}$ long, $1.5 \mathrm{~m}$ wide (at the top) and $1 \mathrm{~m}$ deep). Ditches of $0.5 \mathrm{~m}$ separated the plots. Runoff volume was estimated based on average height of the water (at three sample locations in the trenches), which was calibrated every year with the trench volumes (Tesfay Araya et al., 2011). Every morning, after stirring the water in the trenches, $4 \mathrm{~L}$ of water from each trench was collected and filtered with a funnel and Whatman 42 filter paper (pore size of $2.5 \mu \mathrm{m}$ ). The sediment in the filter paper was oven-dried for 24 hours at $105{ }^{\circ} \mathrm{C}$ and weighed to quantify daily soil loss (Tesfay Araya et al., 2012).

Possible data errors are caused by the storm inflow across the upper plot ditch boundary, leading to influx of flash floods from upslope fields, and the collapse of side plot boundaries, leading to outflux of runoff into the side ditches. Of course, well-known errors of rainfall measurement (such as incidence angle and splash drift) are possible. Furthermore, subsurface flow between plots could occur due to vertic cracking (Návar et al., 2002). Finally, the experimental plots treated with plain tillage do not fully correspond to real-world conventional agriculture, since livestock was not allowed within the experimental station.

\subsection{Field-saturated infiltration measurements}

Measurements of field-saturated infiltration rates were performed with a single ring with constant head infiltrometer on experimental plots to compare CA with plain tillage (PT), but also at 61 locations within the MZZ catchment (45 samples on PT fields and 16 samples on CA fields). The infiltrometer consisted of a metal cylinder with radius of $6.5 \mathrm{~cm}$, which was inserted into the soil to a depth $d$ of $3 \mathrm{~cm}$ and the Mariotte system of the Model 2800 Guelph permeameter (Soilmoisture Equipment, Santa Barbara, California, USA) (see Verbist et al., 2010) was used to maintain a constant water level in the ring $H$ of $10 \mathrm{~cm}$. The water level $h$ in the Mariotte system's reservoir was recorded every minute until a constant (steady state) rate was reached, which occurred after approximately $60 \mathrm{~min}$. The field-saturated infiltration rate $q_{s}\left(\mathrm{~mm} \mathrm{~h}^{-1}\right)$ was then calculated as the average infiltration rate of the last 10 minutes after steady state was reached, with infiltration rate $q\left(\mathrm{~mm} \mathrm{~h}^{-1}\right)$ calculated as:

$q=\frac{\Delta h}{\Delta t} \cdot \frac{A_{\text {reservoir }}}{A_{\text {ring }}}$

where $\Delta h$ height difference of the water in the Mariotte system's reservoir ( $\mathrm{mm}$ ) between two reading $\Delta t(\mathrm{~h})$, and $A_{\text {reservoir }}$ and $A_{\text {ring }}$ are the surface area of the Mariotte system's reservoir and metal ring $\left(\mathrm{mm}^{2}\right)$, respectively.

Potential limitations include soil disturbance during ring insertion and possible edge flow along the ring wall (Reynolds et al., 2000). Furthermore, changes in soil permeability with depth can induce errors (Reynolds et al., 2000).

Field-saturated hydraulic conductivity $\mathrm{K}_{\mathrm{fs}}\left(\mathrm{m} \mathrm{s}^{-1}\right)$ was calculated from $\mathrm{q}_{\mathrm{s}}$ by the equation of Reynolds and Elrick (1990) for ponded infiltration from a single ring with steady flow and constant head:

$$
K_{f s}=\frac{q_{s}}{\frac{H}{C_{1} \cdot d+C_{2} \cdot a}+\frac{1}{\alpha^{*}\left(C_{1} \cdot d+C_{2} \cdot a\right)}+1}=\frac{q_{s}}{3.723}
$$

where height of the constant head $H$ is $0.10 \mathrm{~m}$, ring insertion $d$ is $0.03 \mathrm{~m}$, radius $a$ is $0.065 \mathrm{~m}$, and macroscopic capillary length parameter $\alpha^{*}$ is $12 \mathrm{~m}^{-1}$ (for most structured soils from clays 
through loams, as derived from Reynolds and Elrick (1990)). Calibration coefficients were set as $\mathrm{C}_{1}=0.316 \pi$ and $\mathrm{C}_{2}=0.184 \pi$, since $0.3 \leq d / a \leq 1$ and $5 \mathrm{~cm} \leq H \leq 25 \mathrm{~cm}$ (Torfs, 2008).

At each location of infiltration measurement, several continuous variables (slope gradient, crop height, organic matter and several nominal variables such as crop type, soil type, and texture, were measured and observed. Soil type was derived from the soil map in Nyssen et al. (2008). Crop height was measured with a yardstick from the soil to the very top of the plant, at the location of infiltration measurement. All locations were recorded in the field using the geographic coordinate system WGS84 - UTM 37N.

\subsection{Soil organic carbon and soil texture}

Samples for soil organic carbon and soil texture analysis were taken at the 61 locations of infiltration measurement, whereafter samples were grouped by soil type and mixed within each group. Organic carbon content of each of the ten (seven mixed samples of PT soils and three mixed samples of CA soils) mixed samples was determined by the Walkley-Black procedure on approximately $4 \mathrm{~g}$ of soil (Sarkar and Haldar, 2005). The analysis was performed at the soil laboratory of the Department of Geology and Soil Science of Ghent University. Also, organic carbon content of the mixed samples of CA farmlands were studied. The studied farmlands are located in Hechi (on three fields where CA was practiced till 2010), in the limestone area (two fields on the Igrimulo cliff) and in the basalt area (three fields on the experimental plot and the fields of three practicing farmers). These values were compared with the mixed samples of PT fields; all are adjacent to a CA field.

Soil samples for textural analysis were taken from the topsoil (depth of $5 \mathrm{~cm}$ ) at every location of infiltration measurement. Samples were also grouped by soil type and mixed within each group. Soil texture for the seven mixed samples of PT soils was determined by a combination of two techniques (Sarkar \& Haldar, 2005). Firstly, sand ( $>63 \mu \mathrm{m})$ was separated from silt and clay $(<63 \mu \mathrm{m})$ by wet sieving of $50 \mathrm{~g}$ of the sample with distilled water on a 63 $\mu \mathrm{m}$ sieve. Some $2.5-3 \mathrm{~g}$ of the remaining silt and clay fraction was mixed with $40 \mathrm{ml}$ distilled water, shaken by sonication, and analysed with X-ray sedigraphy. The X-ray intensity for distilled water (baseline) was compared to X-ray intensities of the sinking suspensions to obtain a grain-size classification. Reynolds numbers $R e$ were held between 0.3 and 0.5 to ensure laminarity of the suspension. Error estimation is given by the missing soil at the end of the analysis procedure (50 $\mathrm{g}$ minus total sample weight at the end of the process).

Since the analysis of soil organic carbon and soil texture was performed on mixed samples, results and interpretations should thus be regarded with some caution.

\subsection{Spatial interpolation with topographic information}

Since at each location of infiltration measurement several continuous variables and several nominal variables were measured, regression analysis allowed to link field-saturated infiltration rates with these biophysical variables. As topographic information (digital terrain model DTM) for MZZ was available by data of Shuttle Radar Topography Mission (SRTM; resolution $80 \mathrm{~m} \times 80 \mathrm{~m}$ ), a slope map, calculated in ArcMap®, could be used as a secondary variable for Regression Mapping. Furthermore, an interpolation map using Simple Kriging with local varying means was produced. In contrast to linear regression mapping, which is a deterministic technique, geostatistical techniques (kriging) are stochastic, meaning that they 
provide a number of possible values, with a probability of occurrence. They make use of the spatial correlation between neighbouring observations to predict values at unsampled places. If there is a relation between the predicted variable (e.g. infiltration) and a secondary variable (e.g. slope gradient), multivariate geostatistics can be used allowing to include this secondary information into the interpolation. This additional information results in a more accurate and complete prediction of the variable than without the secondary information.

\subsection{Calibration of RUSLE P factor, Curve Numbers and sediment budget}

In order to model the effect of CA on soil loss and runoff, the Revisited Universal Soil Loss Equation (RUSLE) and the Curve Number Model were applied. RUSLE (Renard et al., 1997), is an empirical model that relates soil loss $\left(\mathrm{t} \mathrm{ha}^{-1} \mathrm{yr}^{-1}\right)$ to a range of biophysical factors. Runoff in small rural catchments can be estimated based on the Curve Number method (SCS, 2004), which predicts storm runoff $(\mathrm{mm})$ from precipitation $(\mathrm{mm})$ for given land characteristics.

RUSLE management factors $\mathrm{P}$ and Pm, and Curve Numbers were estimated for agricultural fields under CA. Following the equations set by Nyssen et al. (2009b), RUSLE P factor was calculated as:

$\mathrm{P}=$ A.(R.K.L.S.C $)^{-1}$

with rain erosivity $R=5.5 \mathrm{Pr}-47$,

soil erodibility $\mathrm{K}=\left[2.1 \mathrm{M}^{1.14}\left(10^{-4}\right)(12-\mathrm{a})+3.25(\mathrm{~b}-2)+2.5(\mathrm{c}-3)\right] \times 0.1317 / 100 \times \mathrm{x} \mathrm{e}^{-0.04(\mathrm{Rc}-10)}$,

slope gradient factor $\mathrm{S}=-1.5+17 /\left(1+\mathrm{e}^{(2.3-6.1 \sin \theta)}\right)$,

slope length factor $\mathrm{L}=0.232 \gamma^{0.48}$,

crop factor $\mathrm{C}=0.21$ for barley and wheat (Nyssen et al., 2009b),

and where $\operatorname{Pr}$ is annual precipitation in $\mathrm{mm} ; \mathrm{M}=(\%$ silt and very fine sand $) \mathrm{x}(100-\%$ clay $)$; $a$ is percentage of organic matter; $b$ is soil structure code, ranging between 1 (very fine granular) and 4 (blocky, platy or massive), set at default value 2; c is permeability class, ranging between 1 (rapid) and 6 (very slow), set at 1; 0.1317 was introduced to convert from the American system to the metric one; Rc is rock fragment cover (in \%); $\theta$ is slope angle and $\gamma$ is slope length (horizontal projection, in $\mathrm{m}$ ).

The $\mathrm{P}$ factor can be split into its three components:

$\mathrm{P}=\mathrm{Pc} \cdot \mathrm{Pn} \cdot \mathrm{Pm}$

with Pc accounting for ploughing and cropping practices, Pn for conservation structures and $\mathrm{Pm}$ for in situ conservation practices. Thus, factor Pm, which is relevant for the effect of $\mathrm{CA}$, can be calculated as

$\mathrm{Pm}=\mathrm{P} /(\mathrm{Pc} . \mathrm{Pn})$

Curve Numbers CN (SCS, 2004) were obtained by solving

$\left\{\begin{array}{l}Q=0 \Leftrightarrow p<0.2 s \\ Q=\frac{(p-0.2 s)^{2}}{(p+0.8 s)} \Leftrightarrow p>0.2 s\end{array}\right.$ 
where $S=\frac{25400}{C N}-254$,

where $Q$ is the runoff $(\mathrm{mm}), p$ is rainfall $(\mathrm{mm})$ and $s(\mathrm{~mm})$ is the potential maximum soil moisture retention after runoff begins, or 'storage'. Based on these equations, for every storm, for both CA and PT, the storage $s$ and Curve Numbers $(\mathrm{CN})$ were calculated and averaged.

A conversion parameter $\varepsilon$ was then calculated as $\mathrm{CN}_{\mathrm{CA}} / \mathrm{CN}_{\mathrm{PT}}$. Since Curve Numbers were calculated for different types of cropland in the study area (Nyssen et al., 2010), they could be adjusted with the conversion parameter $\varepsilon$. Hypothetic catchment runoff after catchment-wide implementation of CA was provided by an area-weighed calculation of a catchment Curve Number.

The sediment budget for MZZ catchment, as calculated by Nyssen et al. (2009a), is expected to be changed if CA would be fully implemented. An average conversion parameter $\varphi$ was calculated from the Total Soil loss Rates (TSR) as the average of $\left(\mathrm{TSR}_{\mathrm{PT}} / \mathrm{TSR}_{\mathrm{CA}}\right)$ on the experimental station for all measured five years $(2005,2008,2009,2010,2011)$. Expected

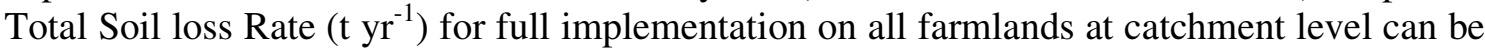
estimated as

$T S R_{C A}^{M Z Z}=\frac{T S R_{T A}^{M Z Z}}{\phi}$

Expected Specific Soil loss Rate $\left(\mathrm{t} \mathrm{ha}^{-1} \mathrm{yr}^{-1}\right)$ can be estimated as

$S S R_{C A}^{M Z Z}=\frac{T S R_{C A}^{M Z Z}}{\text { area }}$

A downslope routing through the sinks (stone bunds, exclosures, check dams) allowed then to recalculate the already known sediment budget of the catchment (Nyssen et al., 2009a). Note that both for soil loss and runoff, it was assumed that differentials measured on the experimental plot would be the same as over the catchment.

\subsection{Calculation of ponding depth}

To understand the effect of the bed-and-furrow system of CA, the effect of water ponding in the furrows or ponding due to increased surface roughness was simulated at parcel scale. Following Anderson and Anderson (2008), the evolution equation for water thickness in overland flow is obtained:

$$
\frac{\partial h}{\partial t}=(r-I)-\frac{d L_{x}}{d x}
$$

Eq. (14) shows ponding height $\mathrm{h}(\mathrm{mm})$ change in time $\mathrm{t}(\mathrm{h})$ as depending on rainfall excess $(\mathrm{r}-\mathrm{I})$ with $\mathrm{r}$ the rainfall rate $(\mathrm{mm} / \mathrm{h})$ and $\mathrm{I}$ the infiltration rate $(\mathrm{mm} / \mathrm{h})$, and discharge $\mathrm{L}_{\mathrm{x}}$ the water volume per unit of time per unit of width $\left(\mathrm{mm}^{2} / \mathrm{h}\right)$ in one spatial dimension $\mathrm{x}$. The equation was solved by numerical approximation, and water flow for measurements in the rainy season of 2011 was simulated. All simulations were performed in $\mathrm{R} \bowtie$ with the mathematical package deSolve (Soetaert and Herman, 2008). Eq. (14) was then used to construct a ponding map from the field-saturated infiltration rate map, showing the locations most prone to ponding.

\section{Results and discussion}




\subsection{Soil-water relations in May Zeg-Zeg}

\subsubsection{Soil properties}

The Vertisols had a relatively high organic carbon content (Table 1), probably enhanced by the presence of smectite clay minerals. Also, OC values were generally higher in the basalt zone than in the limestone zone. In the limestone area there was an increasing OC level on higher positions in the landscape, possibly due to deposition of carbon-rich materials originating from upslope exclosures or from the upslope vertic area.

$* * *$ Table 1 approximately here $* * *$

Texture analysis (Table 2) showed that all Regosols are loamy and Cambisols and Vertisols are clayey. In general, the silt and fine sand content was relatively small, indicating a relatively low erodibility of the soils in the study area. Both in limestone and basalt areas, clay content was relatively large (clay loam, sandy clay loam, and clay). In the limestone area, this can be attributed to the outcropping of weathered parent material.

$* * *$ Table 2 approximately here $* * *$

\subsubsection{Factors controlling infiltration rates}

ANOVA and TukeyHSD test showed that mean field-saturated infiltration value for Vertisols in the basalt area (mean $\left.Q_{s}=17.2 \mathrm{~mm} \mathrm{~h}^{-1} ; \mathrm{n}=6\right)$ was significantly lower $(\mathrm{p}<0.05)$ than mean field-saturated infiltration rate in the basaltic vertic Cambisol area (mean $Q_{s}=616 \mathrm{~mm} \mathrm{~h}^{-1} ; \mathrm{n}$ $=14$ ). This is attributed to the absence of a thick and impervious vertic B horizon in the vertic Cambisols, allowing efficient water flow through the soil profile, as soil cracks are directly connected to lower, stony layers.

$* * *$ Table 3 approximately here $* * *$

Correlation between all measured continuous explanatory factors was calculated by Pearson's product-moment coefficient (Table 3). The strong positive correlation between slope gradient and field-saturated infiltration rates $(r=0.69)$ is most probably related to coarsening of soil texture with slope gradient. Correlations with crop height and elevation were not well pronounced. However, the positive correlation with crop height evidences the positive effect of a larger root network on field-saturated infiltration.

A regression linking slope gradient S (\%) with field-saturated infiltration rate (Fig. 6) seemed a better predictor, especially after removal of outliers on the right, which correspond to Leptosols (measured on cliffs, located only on small parts of the study area and having no agricultural meaning). Excluding Leptosols from the regression procedure yielded the following pedotransfer function (PTF) to predict field-saturated infiltration rates $Q_{s}$ from slope gradient $S$ :

$\mathrm{Q}_{\mathrm{s}}=37.108 \mathrm{~S}$, for $\mathrm{S}<25 \% \quad\left(\mathrm{R}^{2}=0.5605 ; \mathrm{R}^{2}\right.$ adjusted $\left.=0.5498 ; \mathrm{p}=10^{-9}\right)$

$\mathrm{Q}_{\mathrm{s}}=254$, for $\mathrm{S}>25 \%$ (Leptosols).

$* * *$ Figure 6 approximately here $* * *$ 
Since field-saturated infiltration rate is not only dependent on structure and texture of the soil, but also on the occurrence of rock fragments (Cousin et al., 2003; Verbist et al., 2009), the measured effect on slopes $<25 \%$ can be attributed to the presence of more rock fragments on steep slopes. According to Nyssen et al. (2002), rock fragment cover in MZZ is higher on steep slopes, since lateral distribution of rock fragments is dependent on (i) mudflows depositing diamictons including much coarse debris; (ii) intense water erosion and concentrated runoff, which occurred after deforestation and exposed rock fragments at or near to the soil surface; (iii) lateral transport over the soil surface by trampling and tillage; and (iv) rock fall from the cliffs. This generally leads to greater rock fragment cover on steep slopes as compared to level land. Texture of the fine earth fraction $(<2 \mathrm{~mm})$ is generally also more sandy on steeper slopes (Table 2).

\subsubsection{A catchment map of field-saturated infiltration rates}

Field-saturated infiltration rates were mapped, using Eq. (16). An infiltration rate map was calculated by raster calculation. After correction for the Leptosols, a regression map of fieldsaturated infiltration rates was obtained (Fig. 7). As expected, the map shows high infiltration rates at steep slopes (except for slope gradients steeper than 25\%) and slow rates in flat areas. Furthermore, the field-saturated infiltration rates were mapped with Simple Kriging with local varying means. Since both maps show very little differences (probably to too few data for the kriging technique), the easy-to-produce regression map was preferred.

$* * *$ Figure 7 approximately here $* * *$

\subsection{Impacts of conservation agriculture in comparison to plain tillage}

\subsubsection{Soil organic carbon}

Measurements of soil organic carbon content (Table 4) show that soils in CA farms have slightly higher OC content, showing an effect of leaving residual litter for increasing soil organic matter.

$* * *$ Table 4 approximately here $* * *$

\subsubsection{Runoff}

Clearly, runoff is mainly produced through the infiltration excess rather than through the soil saturation mechanism. Indeed, overland flow could not be produced through saturation, since water tables never reach the surface at the steeper slopes. Nyssen et al. (2010) show that even in the lowest places of the catchment the water table almost never reaches the surface. At the experimental site, runoff depth and coefficients were lowest for CA during all six years. As reported by Tesfay Araya et al. (2012), average runoff depth during the growing season (JuneSeptember) for all six years (2005-2011 except 2006) was $78.7 \mathrm{~mm}$ under CA and $126.2 \mathrm{~mm}$ under PT. Average runoff coefficient of all five years during the growing season was significantly less in CA (18.8\%) treatments compared to PT (30.4\%). Furthermore, the runoff coefficient did not increase with increasing cumulative rainfall during the rainy season.

For every day with runoff generation (assumed to correspond to one storm), for both CA and PT, the storage $s$ and Curve Numbers $(\mathrm{CN})$ were calculated. The average for $\mathrm{CA}\left(\mathrm{s}_{\mathrm{CA}}\right)$ was 
$29.6 \mathrm{~mm}$ and for PT $\left(\mathrm{S}_{\mathrm{PT}}\right) 18.4 \mathrm{~mm}$. The conversion parameter $\varepsilon\left(\mathrm{CN}_{\mathrm{CA}} / \mathrm{CN}_{\mathrm{PT}}\right)$ was $96.3 \%$. Since $\mathrm{CN}$ had been calculated for different types of conventionally plain tilled cropland (Nyssen et al., 2010), their values can be adjusted for CA with the conversion parameter $\varepsilon=$ 0.963 (Table 5). The effect of CA on runoff from cropland is more pronounced than the effect of other conservation measures, such as stone bunds, as for example CN of a PT farmland with 'zero' grazing and good stone bunds is 77.3 but $\mathrm{CN}$ of a CA farmland with 'zero' grazing and no stone bunds is 75.8 .

$* * *$ Table 5 approximately here $* * *$

Catchment runoff under a scenario of catchment-wide implementation of CA was calculated, using Curve Numbers and area of all land use and management types. With the new Curve Numbers (Table 5), a weighted average catchment Curve Number was calculated for catchment-wide implementation of CA (Table 6).

$* * *$ Table 6 approximately here $* * *$

As an illustration, the catchment runoff was simulated with Eq. (10), based on catchment weighted average CN 68.9 (PT) and 67.2 (catchment implementation of CA), and using the 2011 rainfall data. Simulated runoff from this catchment that was treated with physical SWC structures occurred on eight days from June 2011 till September 2011, causing a predicted total runoff depth of $23.5 \mathrm{~mm}$ with $\mathrm{CA}$ implementation and $27.9 \mathrm{~mm}$ with PT implementation.

Finally, a linear relationship (Fig. 8a) between daily rainfall ( $\mathrm{mm}$ ) and daily runoff $(\mathrm{mm})$ was calculated for the average of the three CA plots and for the three PT plots for 2011. As expected, the slope of the CA-curve was lower (due to lower runoff coefficients). Both $\mathrm{R}^{2}$ values are very high, illustrating the strong relationship between rainfall and runoff.

$* * *$ Figure 8 approximately here $* * *$

\subsubsection{Soil loss}

Mean soil loss over five years for CA $\left(14.4 \mathrm{t} \mathrm{ha}^{-1}\right)$ was significantly less than from PT (35.4 t $\mathrm{ha}^{-1}$ ), as reported by Tesfay Araya et al. (2012). For 2011, mean soil loss was $16.2 \mathrm{t} \mathrm{ha}^{-1}$ (CA) and $33.0 \mathrm{t} \mathrm{ha}^{-1}(\mathrm{PT})$. Highest soil loss for both treatments was observed with grass pea cropping in 2009 and 2011. This can be attributed to some intense convectional storms in these years, and to the lower canopy interception depth of grass pea. Hence, the years 2009 and 2011 were treated as data outliers and not taken into account in RUSLE calculations.

The management factor P was calibrated (Table 7) by isolation in the RUSLE equation (eq. 3 ), and was calculated for plain tillage as 0.88 , whereas for CA it was calculated as 0.40 . Mean factor $\mathrm{Pm}$ for in situ conservation was calculated as $\mathrm{P} /(\mathrm{Pc} \times \mathrm{Pn})=0.45$ with $\mathrm{Pc}$ the subfactor for ploughing and cropping practices (0.9). Pn, the subfactor for conservation structures, was set at 1 as all measurements took place over a slope length that was less than 
the interval between two stone bunds. The effect of CA was also incorporated in the erodibility factor K, since organic carbon content was higher in soils treated with CA.

$* * *$ Table 7 approximately here $* * *$

Finally, a linear relationship (Fig. 8b) between daily rainfall (mm) and daily soil loss ( $\left.\mathrm{t} \mathrm{ha}^{-1}\right)$ was calculated for the average of the three CA plots and for the three PT plots. As expected, the slope of the CA-curve was lower. Both $\mathrm{R}^{2}$ values are very high, illustrating the strong relationship between rainfall and soil loss.

\subsubsection{Field-saturated infiltration rates under plain tillage and conservation agriculture}

Field-saturated infiltration rates Q of $11 \mathrm{CA}$ farmlands (3 in Hechi, 2 at Igrimulo cliff, 3 at the experimental plot and $3 \mathrm{CA}$ fields in the basalt Vertic Cambisol area) were compared to their 11 adjacent conventionally plain tilled fields. The t-test $(\alpha=0.05)$ shows that infiltration rates were significantly higher on the $\mathrm{CA}$ fields. Furthermore, one random field couple was measured in-depth. The couple consisted of a CA farmer's field in the basalt area (where infiltration was measured 8 times), and it's neighbouring field with PT (also 8 infiltration measurements). Both fields belong to the same soil type (Vertic Cambisol), have the same slope gradient (6\%), had the same crop type (barley) and had approximately the same crop height. Mean Q for CA fields was $800.9 \mathrm{~mm} / \mathrm{h}$ and mean Q for PT was $891.5 \mathrm{~mm} / \mathrm{h}$. A t-test $(\alpha=0.05)$ showed, ceteris paribus, however no significant differences between CA and PT. Since in the first approach, field-saturated infiltration rates are also influenced by biophysical factors other than the application of CA, the second approach is preferred. Hence, though a tendency seems present, field-saturated infiltration was ceteris paribus not (yet) significantly influenced by the application of CA.

\subsubsection{Ponding}

Although infiltration measurements with a single ring infiltrometer did not show significant differences in infiltration rate between CA and PT, this does not mean that CA does not change water infiltration. Due to increased surface roughness (furrows and litter), water is retained at the surface and allowed to pond for longer time, which promotes infiltration. As daily infiltrated water is thus dependent both on hydaulic conductivity and the delaying effect of the roughness, it can be estimated for 2011 rains by considering daily rainfall (mm) minus daily runoff $(\mathrm{mm})$. This results in an average daily infiltrated water amount of $13.2 \mathrm{~mm}(\mathrm{CA})$ and $10.8 \mathrm{~mm}(\mathrm{PT})$ and an infiltration coefficient, i.e. the average of daily infiltrated water divided by daily rainfall, of $82.3 \%$ for CA and $67.5 \%$ for PT (complement of the runoff coefficient).

A linear relationship (Fig. 8c) between daily rainfall ( $\mathrm{mm}$ ) and daily infiltration depth (mm) was found for the average of the three CA plots and for the three PT plots. As expected, the slope of the CA-curve was steeper. Both $\mathrm{R}^{2}$ values were very high ( 0.951 for PT and 0.974 for CA), illustrating the strong relationship between daily rainfall and daily infiltrated water.

Simulations of the ponding equation were performed taking a 5-year average runoff coefficient (RC) for CA of 0.19 and for PT of 0.30 (Tesfay Araya et al., 2011), in order to assess the impact of storm duration, rainfall depth and parcel length on CA and PT water trapping efficiency. Hence, runoff $\mathrm{F}(\mathrm{mm} / \mathrm{h})$ can be approximated by setting $\mathrm{F}=\mathrm{RC} * \mathrm{r}$. 
Keeping infiltration constant, a steady infiltration rate of $17 \mathrm{~mm} \mathrm{~h}^{-1}$, as measured on average for the Vertic Cambisol on the experimental plot, was taken. After solving the partial differential equation with deSolve (numerical approximations), it appeared that ponding increased with long storm durations (Fig. 9). However, this effect was only discernible for rainfall durations of more than one hour. Thus, the impact of rainfall duration on ponding was negligible for the short heavy storms of North Ethiopia (Fig. 9). Since this Horton overland model seems to simulate runoff quite realistically, infiltration excess should indeed be the main regional runoff mechanism, inducing temporary ponding if surface depressions are present.

$* * *$ Figure 9 approximately here $* * *$

A first projection assessed the impact of rainfall depth on the ponding effect for a $1 \mathrm{~h}$ storm. As the upper ditch of the experimental plots captures all upslope runoff water, $\mathrm{L}_{\mathrm{upper}}=0$, all water is collected in the downslope collector trench:

$\left\{\begin{array}{l}\frac{d L_{x}}{d x}=L_{\text {upper }}-L_{\text {trench }}=0-L_{\text {trench }}=F \\ h=\int_{t_{0}}^{t_{1}}(r-I-F) d t=(r-I-F) . \Delta t=r-F-I=r-(R C . r)-I\end{array}\right.$

When solving these equations, it became clear that the ponding effect on CA (beneficial effect as compared to PT) caused by increased surface roughness would be more pronounced for larger rainfall events, since the lag between the CA and PT curves increases with rainfall (Fig. $10)$.

At steady state, a second projection assessed the impact of parcel length $\mathrm{x}$ :

$$
\frac{d L_{x}}{d x}=r-I \text { or } L=\int_{0}^{x}(r-I) d x=(r-I) \cdot x .
$$

Hence, merging eq. (17) into the Darcy-Weisbach formula (Anderson \& Anderson, 2008), leads to:

$$
L=\frac{h^{3 / 2}}{f} \sqrt{S g} \Rightarrow(r-I) \cdot x=\frac{h^{3 / 2}}{f} \sqrt{S g} \Leftrightarrow h=\left(\frac{(r-I) . f}{\sqrt{S . g}}\right)^{2 / 3} . x^{2 / 3}
$$

where $\mathrm{f}$ is the Darcy-Weisbach friction factor (64/Reynolds number, set at 0.04 for laminar flow (Moody, 1944)), $\mathrm{g}$ is standard gravity $9.81 \mathrm{~m} \mathrm{~s}^{-2}$, and slope gradient is $6 \%$.

Solving Eq. (18) for a heavy storm of $40 \mathrm{~mm}$ and an infiltration rate of $17 \mathrm{~mm} \mathrm{~h}^{-1}$ (Fig. 10) showed that

the ponding effect due to increased surface roughness on CA is more pronounced on fields with long parcel lengths, since the lag between CA graph and PT graph increases with runoff length (Fig. 10).

$* * *$ Figure 10 approximately here $* * *$ 
Finally, a ponding map was constructed using the field-saturated infiltration rate map (Fig. 11). GIS calculation showed that the mean of all 1728 spatial pixels of this map is $407 \mathrm{~mm} \mathrm{~h}^{-1}$ $\pm 196 \mathrm{~mm} \mathrm{~h}^{-1}$. Then, the $33 \%$ pixels most prone to ponding were detected, by calculating the $33 \%$ boundary infiltration rate $\mathrm{I}_{\mathrm{b}}$ and by assuming normal distribution: $0.33=\Phi(-0.44)=\Phi\left(\frac{I_{b}-407}{196}\right)$, so $\mathrm{I}_{\mathrm{b}}$ is $321 \mathrm{~mm} \mathrm{~h}^{-1}$. A binary risk map was constructed (Fig. 11) with infiltration rates lower than $321 \mathrm{~mm} \mathrm{~h}^{-1}$. In this calculation, the earlier discussed (section 3.1.2) Leptosol areas with low infiltration rates and which are generally not suitable for agriculture (slope gradients $>25 \%$ ) were discarded. Since it is proven that the ponding effect is the determining factor in the effect of CA on soil-water behavior, this map (Fig. 11) shows the preferential locations for CA implementation.

$* * *$ Figure 11 approximately here $* * *$

\subsection{Simulation of catchment runoff and soil loss for six future policy scenarios}

All collected information was used to predict soil and water behavior under future (2040) climate conditions, and to compare the impact of different kinds of land management. Six policy scenarios were designed (Table 8), in which runoff, soil loss and sediment budgets were calculated.

$* * *$ Table 8 approximately here $* * *$

A first scenario accounts for a situation without any conservation practices, and without any climate change (as the situation of 2000). A second scenario accounts for a situation without any conservation measures but with an increase in precipitation of $14.7 \%$ by 2040 (see section 2.1). A third scenario accounts for a situation without climate change, but with application of plain tillage and catchment management (as the situation of 2006). A fourth scenario accounts for plain tillage with catchment management under conditions of climate change. The fifth and sixth scenarios assess soil-water behavior under full implementation of CA (without and with climate change respectively).

In order to assess the sediment budget under CA, the budget of Nyssen et al. (2009a) was recalculated. The average conversion parameter $\varphi$ for implementation of CA on farmland was calculated as 1.913. Then, application of Eq. (12) resulted in an expected Total Soil Loss ( $\mathrm{t} \mathrm{yr}^{-}$ ${ }^{1}$ ) for full future implementation of CA on catchment level of $320.9 \mathrm{t} \mathrm{yr}^{-1}$ for free grazing policy and $260.2 \mathrm{t} \mathrm{yr}^{-1}$ for non grazing policy (Table 9). Expected Specific Soil Loss ( $\mathrm{t} \mathrm{ha}^{-1} \mathrm{yr}^{-}$ ${ }^{1}$ ) was estimated with Eq. (13) as $5.2 \mathrm{t} \mathrm{ha}^{-1} \mathrm{yr}^{-1}$ for free grazing policy and $4.1 \mathrm{t} \mathrm{ha}^{-1} \mathrm{yr}^{-1}$ for non grazing policy.

$* * *$ Table 9 approximately here $* * *$

With full implementation of CA, the Total Soil Loss due to sheet and rill erosion in cropland would become $581 \mathrm{t} \mathrm{yr}^{-1}$ instead of $1109 \mathrm{t} \mathrm{yr}^{-1}$. Sheet and rill erosion of rangelands $\left(212 \mathrm{t} \mathrm{yr}^{-}\right.$ ${ }^{1}$ ), sheet and rill erosion in exclosures and grassland $\left(149 \mathrm{t} \mathrm{yr}^{-1}\right)$ and sheet and gully erosion $\left(206 \mathrm{t} \mathrm{yr}^{-1}\right)$ are taken the same as in 2006. Gully erosion may however be affected by a decreased runoff coefficient. The $1109 \mathrm{t} \mathrm{yr}^{-1}$ eroded material was attributed to sediment sinks and yield in the proportions of the 2006 budget. Using the recalculated values, a new sediment budget for an assumed full implementation of CA on farmland was calculated (Fig. 12). Estimations show the huge impact CA would have on the sediment budget of MZZ, with overall catchment sediment yield decreasing to $1.3 \mathrm{t} \mathrm{ha}^{-1} \mathrm{yr}^{-1}$.

$* * *$ Figure 12 approximately here $* * *$ 
Scenarios II, IV and VI assess the impact of global warming (IPCC scenario A1FI) on plain tilled land. The effect on soil loss for the experimental plot was calculated by inserting the simulated precipitation values (EdGCM) into the R factor of the RUSLE equation. For these scenarios (increase in precipitation, full application of plain tillage) the increase in factor $\mathrm{R}$ would result in a yearly soil loss of $30.2 \mathrm{t} \mathrm{ha}^{-1}$, a sharp increase of soil loss as compared to the current situation (Table 10).

$* * *$ Table 10 approximately here $* * *$

All effects of the six scenarios on runoff, soil loss, sediment budget and organic matter are summarized in Table 11. Comparing scenario V with scenarios III and I, shows that in a steady climate situation, soil loss and runoff from farmlands is greatly altered by applying conservation measures (stone bunds, exclosures and check dams), and notably by applying CA. Comparing scenario VI with scenario IV shows the high efficiency of CA in reducing soil loss under a changing climate (full compensation of the climate effect if CA is applied). At catchment scale, soil losses would be even less than today under plain tillage (scenario III). Comparison of scenario III with scenario IV shows the danger of climate change for land degradation, if catchment management is not well implemented. However, if soil and water is well managed, with attention to environmental conservation, the future increase in precipitation could act in a beneficial way with greater green water availability.

$* * *$ Table 11 approximately here $* * *$

\section{Conclusions}

This study analyzed the biophysical impact of conservation agriculture at experimental locations in the MZZ catchment, and tried to predict the consequences on runoff and soil loss for large-scale future implementation on catchment-level. Firstly, the current soil-water relations in MZZ catchment were investigated. Texture analysis showed all soils have loam to clay texture. Field measurements showed that infiltration rates in Vertisols in the basalt area are significantly lower than infiltration rates in the basaltic Vertic Cambisol area, probably due to the lack of a thick Vertic horizon in Vertic Cambisols. Linear regression showed also that field-saturated infiltration is higher on fields with high crop stand (probably related to enhanced infiltration due to a larger root network) and on steeper slopes. As the experimental variograms show, infiltration rates were autocorrelated within distances of $200 \mathrm{~m}$, and slope gradients were autocorrelated within distances of $500 \mathrm{~m}$. Mapping of infiltration with $80 \mathrm{~m} \mathrm{x}$ $80 \mathrm{~m}$ resolution of SRTM terrain data thus yields a fair approximation. The relation of infiltration with slope was used to postulate a pedotransfer function. An infiltration map was produced (applying linear regression) showing estimated field-saturated infiltration rates in MZZ catchment, that increase with slope steepness, with the notable exception of low infiltration rates on steep slopes with shallow soils or rock outcrops.

Secondly, CA was compared to PT on several experimental fields. Runoff was significantly reduced by practicing CA (runoff coefficient down from $30.4 \%$ for PT to $18.8 \%$ ), and Curve Numbers were lower. Also, soil loss was heavily reduced by CA. RUSLE management factors P (0.40) and Pm (0.45) were calibrated. Measurements of soil organic carbon showed $\mathrm{CA}$ adds more organic matter to the soil (by leaving litter). Field-saturated infiltration rates were not significantly changed by CA, since CA hardly alters deep soil structure. However, $\mathrm{CA}$ does enhance infiltration of rain. Increased surface roughness and furrows allow water to pond and infiltrate with a certain delay. A volume balance was used to model this ponding 
effect. Simulations show that the ponding effect due to increased surface roughness on CA is hardly influenced by the short Ethiopian storm durations, but is most effective for heavy rainfall, and on fields with long parcel lengths.

Also, the adaptation of existing sediment budgets for MZZ shows that Total Soil Loss due to sheet and rill erosion in cropland would become $581 \mathrm{t} \mathrm{yr}^{-1}$ instead of $1109 \mathrm{t} \mathrm{yr}^{-1}$, if CA would be practiced at large scale in MZZ. Using the precipitation projections of IPCC scenario A1FI, CA would be able to mitigate the effect of increased rainfall on soil loss and runoff coefficients in the $21^{\text {st }}$ century. Thus, CA can have a strong impact on the sediment budgets of catchments in semiarid areas, especially under conditions of a changing climate.

Further research for assessing the impact of CA on soil-water characteristics is required. CA in our study was a broad concept, consisting of (i) a bed-and-furrow component, (ii) a residue component and (iii) a zero-plowing component. It would be useful to separate the constituting aspects in an experimental setting. Hence, the relative importance of every component could be quantified.

As this research shows, it is clear that the bed-and-furrow system contributes notably to soilwater quality improvements; the effect of the residue component and the zero-plowing component are less clear. Also, the ponding effect due to increased surface roughness should be tested with hydraulic measurements of the water flow. Furthermore, in order to implement $\mathrm{CA}$ at catchment level, it is necessary to examine the acceptance of this technique by local farmers, and assess the social and economic framework that influences this adoption process.

\section{Acknowledgements}

This study would not have been possible without the enormous support, friendship and help of our translator Yohannes, the support and kindliness of the many farmers who let us work on their fields, the friendship and help of Lys Moulaert, the support and financial help of the Belgo-Ethiopian VLIR MU-IUC programme, the technical assistance of UGent and MU laboratory staff, and the work of the field technicians in the CA project.

\section{References}

Anderson, R., Anderson, S., 2008. Geomorphology - the mechanics and chemistry of landscapes. Cambridge University Press, Cambridge.

Berakhi, O., Brancaccio, L., Calderoni, G., Coltorti, M., Dramis, F., Umer, M.M., 1998. The Mai Maikden sedimentary sequence: a reference point for the environmental evolution of the Highlands of Northern Ethiopia. Geomorphology 23, 127-138.

Chandler, M.A., Richards, S.J., Shopsin, M.J., 2005. EdGCM: Enhancing climate science education through climate modeling research projects, 85th Annual Meeting of the American Meteorological Society, 14th Symposium on Education. NASA, San Diego, CA, USA, p. P1.5.

Cousin, I., Nicoullaud, B., Coutadeur, C., 2003. Influence of rock fragments on the water retention and water percolation in a calcareous soil. Catena 53, 97-114. 
Goebel, W., Odenyo, V., 1984. Ethiopia. Agroclimatic resources inventory for land-use planning. Technical Report DP/ETH/78/003 (2 vols.). Ministry of Agriculture, Land Use Planning and Regulatory Department, UNDP,FAO.

Goovaerts, P., 1997. Geostatistics for Natural Resources Evalation. Oxford University Press, New York.

Goovaerts, P., 1999. Using elevation to aid the geostatistical mapping of rainfall erosivity. Catena 34, 227-242.

Hansen, J., Russell, G., Rind, D., Stone, P., Lacis, A., Lebedeff, S., Ruedy, R., Travis, L., 1983. Efficient Three-Dimensional Global Models for Climate Studies: Models I and II. Monthly Weather Review 111, 609-662.

Hengl, T., Heuvelink, G.B.M., Stein, A., 2004. A generic framework for spatial prediction of soil variables based on regression-kriging. Geoderma 120, 75-93.

Isaaks, E., Srivastava, R., 1989. An introduction to applied geostatistics. Oxford University Press, Oxford.

Merla, G., Abbate, E., Azzaroli, A., Bruni, P., Canuti, P., Fazzuoli, M., Sagri, M., Tacconi, P., 1979. A geological map of Ethiopia and Somalia (1973) 1:2.000.000 and comment. University of Florence, Firenze, Italy.

Moody, L.F., 1944. Friction factors for pipe flow. Transactions of the ASME 66, 671-684.

Návar, J., Mendez, J., Bryan, R.B., Kuhn, N.J., 2002. The contribution of shrinkage cracks to bypass flow during simulated and natural rainfall experiments in northeastern Mexico. Canadian Journal of Soil Science 82, 65-74.

Nyssen, J., Clymans, W., Descheemaeker, K., Poesen, J., Vandecasteele, I., Vanmaercke, M., Mitiku Haile, Nigussie Haregeweyn, Moeyersons, J., Martens, K., Amanuel Zenebe, Van Camp, M., Tesfamichael Gebreyohannes, Deckers, J., Walraevens, K., 2010. Impact of soil and water conservation on catchment hydrological response - a case in northern Ethiopia. Hydrological Processes 24, 1880-1895.

Nyssen, J., Clymans, W., Poesen, J., Vandecasteele, I., De Baets, S., Nigussie Haregeweyn, Naudts, J., Amanuel Hadera, Moeyersons, J., Mitiku Haile, Deckers, J., 2009a. How soil conservation affects the catchment sediment budget - a comprehensive study in the north Ethiopian highlands. Earth Surface Processes and Landforms 34, 1216-1233.

Nyssen, J., Govaerts, B., Tesfay Araya, Cornelis, W.M., Bauer, H., Mitiku Haile, Sayre, K., Deckers, J., 2011. The use of the marasha ard plough for conservation agriculture in Northern Ethiopia. Agron. Sustain. Dev. 31, 287-297.

Nyssen, J., Naudts, J., De Geyndt, K., Mitiku Haile, Poesen, J., Moeyersons, J., Deckers, J., 2008. Soils and land use in the Tigray highlands (Northern Ethiopia). Land Degradation \& Development 19, 257-274.

Nyssen, J., Poesen, J., Mitiku Haile, Moeyersons, J., Deckers, J., Hurni, H., 2009b. Effects of land use and land cover on sheet and rill erosion rates in the Tigray Highlands, Ethiopia. Zeitschrift für Geomorphologie 53, 171-197.

Nyssen, J., Poesen, J., Moeyersons, J., Deckers, J., Haile, M., Lang, A., 2004. Human impact on the environment in the Ethiopian and Eritrean highlands - a state of the art. Earth-Science Reviews 64, 273-320. 
Nyssen, J., Poesen, J., Moeyersons, J., Lavrysen, E., Mitiku Haile, Deckers, J., 2002. Spatial distribution of rock fragments in cultivated soils in northern Ethiopia as affected by lateral and vertical displacement processes. Geomorphology 43, 1-16.

Nyssen, J., Vandenreyken, H., Poesen, J., Moeyersons, J., Deckers, J., Mitiku Haile, Salles, C., Govers, G., 2005. Rainfall erosivity and variability in the Northern Ethiopian Highlands. Journal of Hydrology 311, 172-187.

Renard, K.G., Foster, G.R., Weesies, G.A., McCool, D.K., Yoder, D.C., 1997. Predicting soil erosion by water: a guide to conservation planning with the Revised Universal Soil Loss Equation (RUSLE). Agriculture Handbook 703. United States Department of Agriculture, Washington.

Reynolds, W., Elrick, D., 1990. Ponded infiltration from a single ring - analysis of steady flow. Soil Science Society of America Journal 54, 1233-1241.

Reynolds, W.D., Bowman, B.T., Brunke, R.R., Drury, C.F., Tan, C.S., 2000. Comparison of Tension Infiltrometer, Pressure Infiltrometer, and Soil Core Estimates of Saturated Hydraulic Conductivity. Soil Sci. Soc. Am. J. 64, 478-484.

Riddle, E.E., Cook, K.H., 2008. Abrupt rainfall transitions over the Greater Horn of Africa: Observations and regional model simulations. J. Geophys. Res. 113, D15109.

Sarkar, D., Haldar, A., 2005. Physical and chemical methods in soil analysis - fundamental concepts of analytical chemistry and instrumental techniques. New Age International Publishers, New Delhi.

SCS, 2004. Hydrology. National Engineering Handbook, Supplement A, Section 4, Chapter 10. Soil Conservation Service, USDA, Washington, D.C., USA.

Segele, Z.T., Lamb, P.J., Leslie, L.M., 2009. Large-scale atmospheric circulation and global sea surface temperature associations with Horn of Africa June-September rainfall. International Journal of Climatology 29, 1075-1100.

Soetaert, K., Herman, P., 2008. A Practical Guide to Ecological Modelling: Using R as a Simulation Platform. Springer, London.

Tesfay Araya, Cornelis, W.M., Nyssen, J., Govaerts, B., Fekadu Getnet, Bauer, H., Kassa Amare, Raes, D., Mitiku Haile, Deckers, J., 2012. Medium-term effects of conservation agriculture based cropping systems for sustainable soil and water management and crop productivity in the Ethiopian highlands. Field Crops Research 132, 53-62.

Tesfay Araya, Cornelis, W.M., Nyssen, J., Govaerts, B., Tewodros Gebregziabher, Tigist Oicha, Fekadu Getnet, Raes, D., Mitiku Haile, Deckers, J., Sayre, K.D., 2011. Effects of conservation agriculture on runoff, soil loss and crop yield under rain fed conditions in Tigray, Northern Ethiopia. Soil \& Tillage Research 27, 404-414.

Tobler, W., 1970. A computer movie simulating urban growth in the Detroit region. Economic Geography 46, 234-240.

Torfs, S., 2008. Evaluation of field methods to determine hydraulic properties of stony soils in arid zones of Chile. Unpublished thesis. Ghent University, Faculty Bio-engineering, Ghent.

Vanmaercke, M., Zenebe, A., Poesen, J., Nyssen, J., Verstraeten, G., Deckers, J., 2010. Sediment dynamics and the role of flash floods in sediment export from medium-sized catchments: a case study from the semi-arid tropical highlands in northern Ethiopia. Journal of Soils and Sediments 10, 611-627. 
Verfaillie, E., Du Four, I., Van Meirvenne, M., Van Lancker, V., 2009. Geostatistical modeling of sedimentological parameters using multi-scale terrain variables: application along the Belgian Part of the North Sea. International Journal of Geographical Information Science 23, 135-150.

Verfaillie, E., Van Lancker, V., Van Meirvenne, M., 2006. Multivariate geostatistics for the predictive modelling of the surficial sand distribution in shelf seas. Continental Shelf Research 26, 2454-2468.

Williams, A.P., Funk, C., 2011. A westward extension of the warm pool leads to a westward extension of the Walker circulation, drying eastern Africa. Clim Dyn 37, 2417-2435.

\section{Figures}

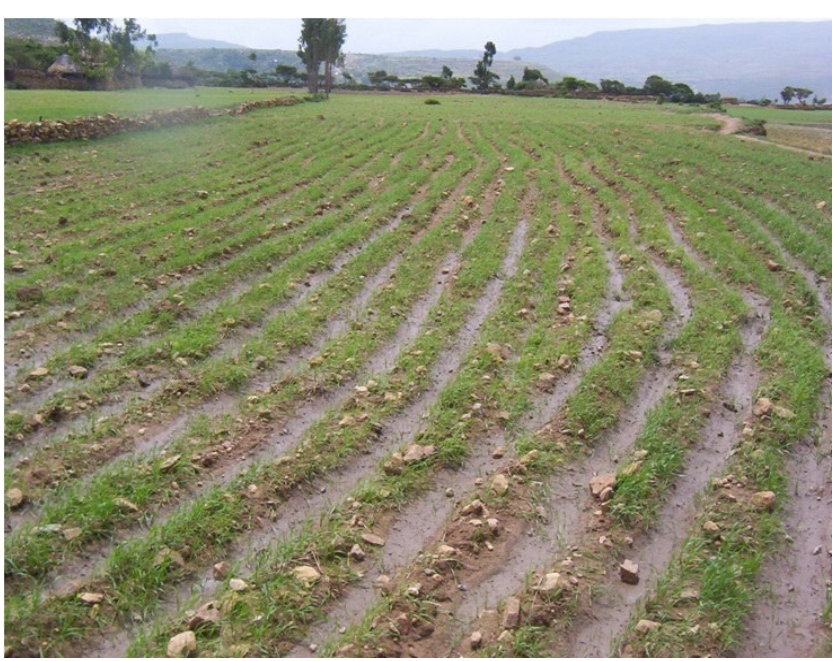

Figure 1. Conservation agriculture farming at Igrimulo in MZZ catchment (derdero+ permanent beds shaped by the local plough) enhances ponding; the wheat crop has just germinated and grows on the ridges; the farmland is sloping down to the right. 


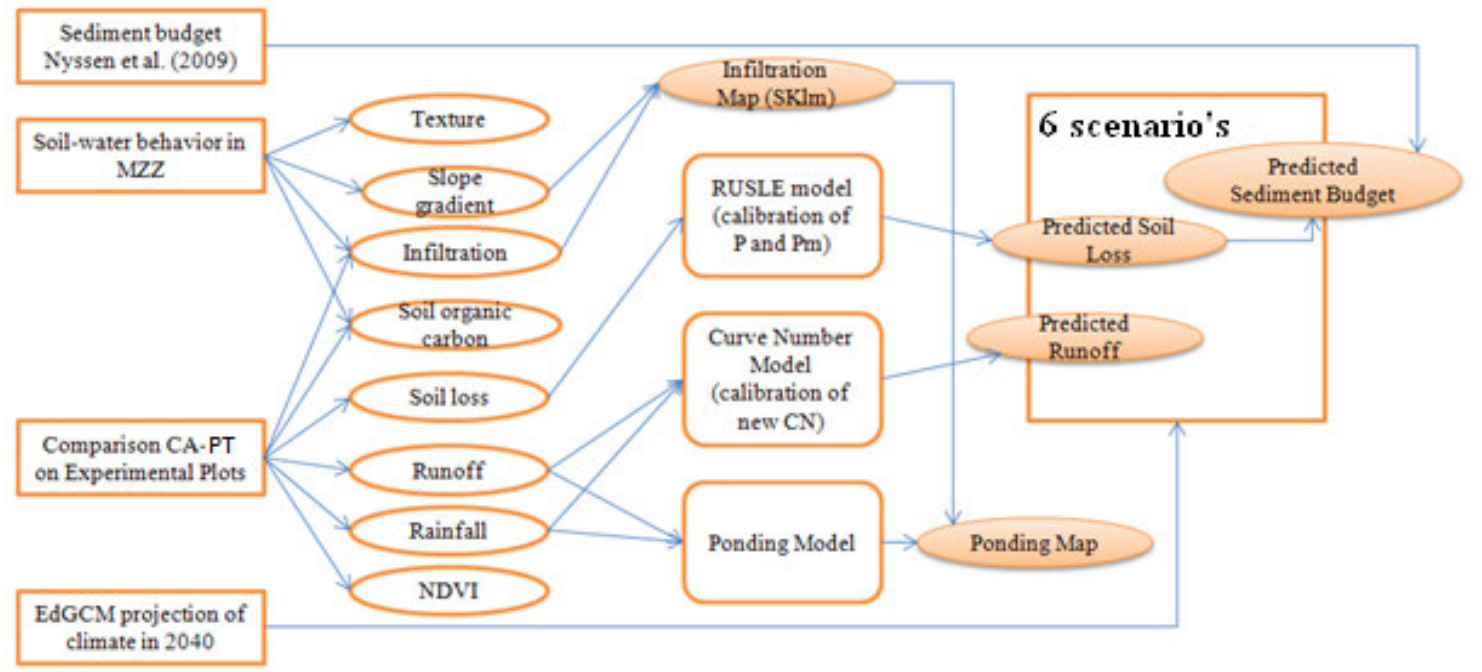

Figure 2. Research setup. Rectangles show scientific goals, ovals show measured biophysical variables, rounded rectangles show empirical prediction models, filled ovals show output and arrows show connections in-between. 

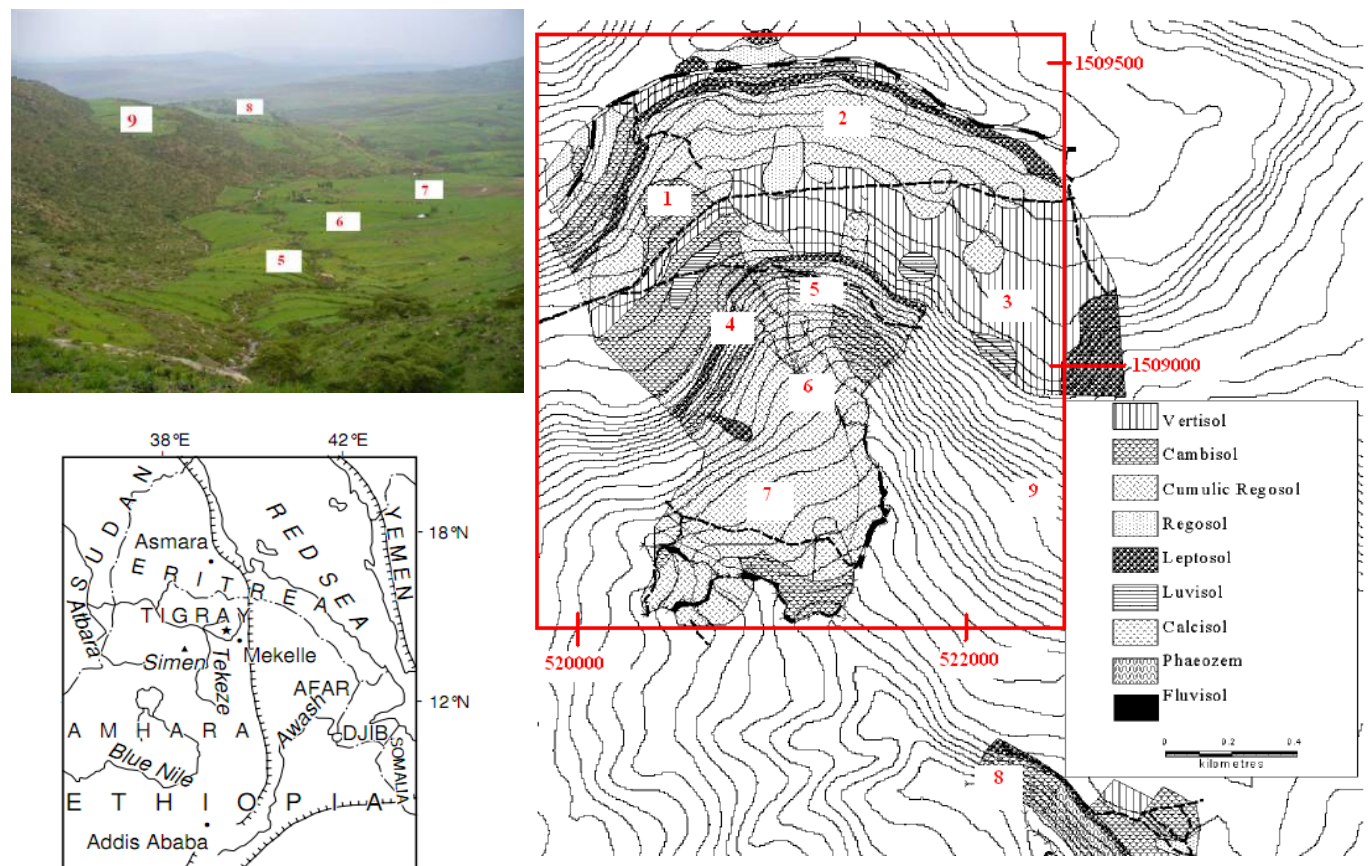

Figure 3. Location of the study area May-Zegzeg, view over the lower part of the catchment, and soil map (after Nyssen et al., 2008). In the northern, upper part (Zenako) soils are derived from basalt and comprise Vertic Cambisols (1), Regosols (2) and Vertisols (3). A sandstone cliff (4) separates Zenako from the lower limestone part (Argaka). Argaka consists of upper (5), middle (6) and lower parts (7) of Regosols. The village of Hechi is located to the southeast (8) and the cliffy area of Igrimulo lies more to the east (9). The red frame (with coordinates in UTM $37 \mathrm{~N}$ ) corresponds to the area indicated in subsequent maps. 


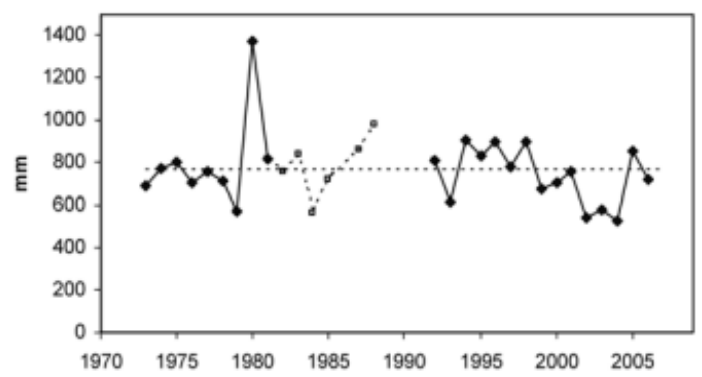

Figure 4. Annual precipitation in Hagere Selam (www.ethiomet.gov.et). Missing data correspond to civil war and the period thereafter. For the period 1982-1988 missing data were predicted through correlation with data of a station near Mekelle (Nyssen et al., 2009b). 

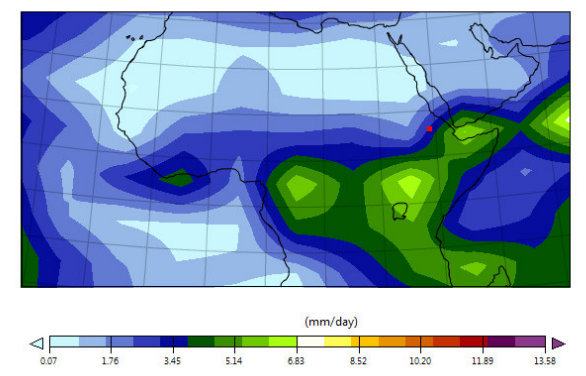

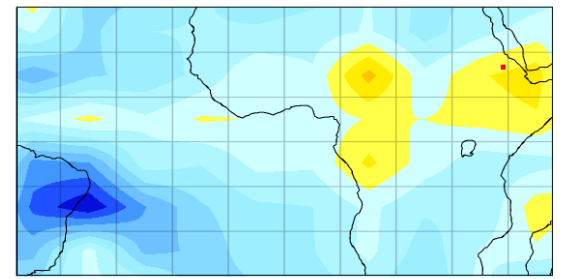

(mm/day)

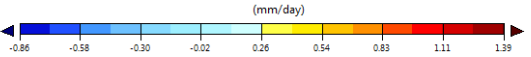

Figure 5. Simulations of IPCC scenario A1FI in EdGCM (Albers projection) (Chandler et al., 2005). Left map shows predicted average precipitation for 1972-1984; right map shows difference of average precipitation between 2040-2045 and 1972-1984. Study area is indicated with a red dot.

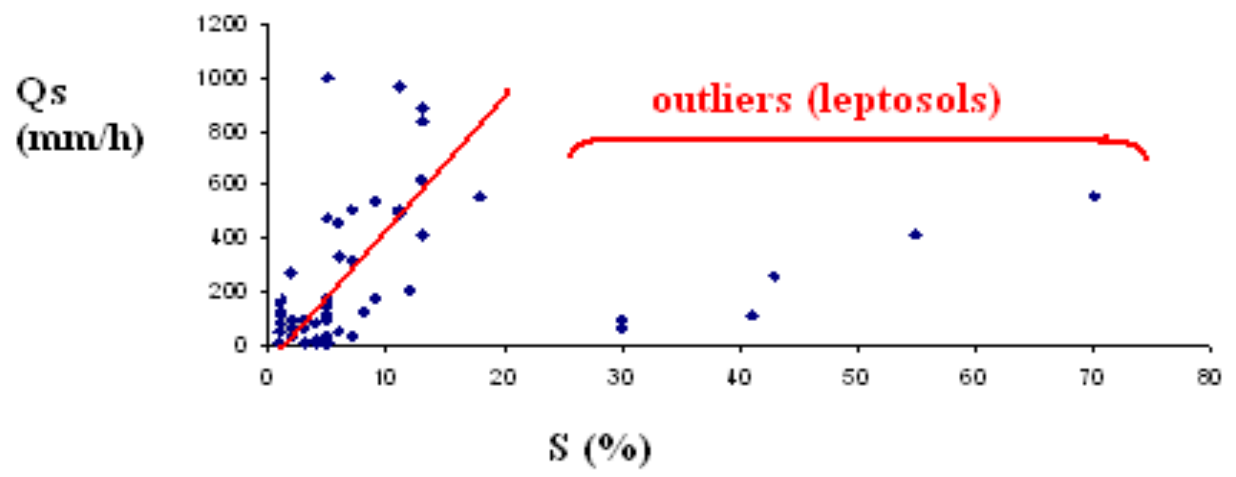

Figure 6. Field-saturated infiltration rates $\left(\mathrm{Q}_{\mathrm{s}}\right)$ as a function of slope gradient $(\mathrm{S})$. Values of $\mathrm{Q}_{\mathrm{s}}$ are treated as outliers for $\mathrm{S}>25 \%$. 


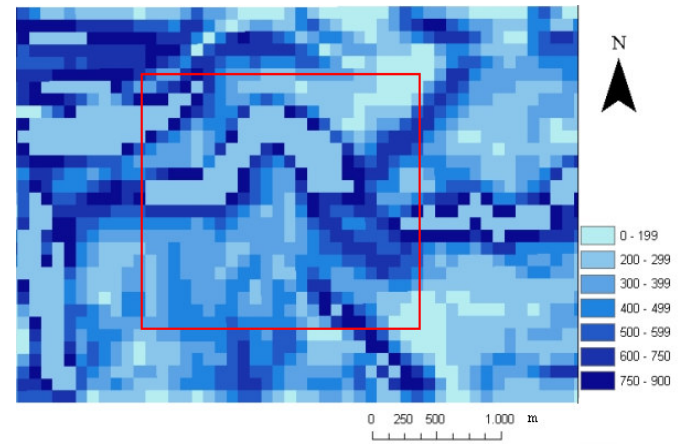

Figure 7. Field-saturated infiltration rate map $\left(\mathrm{mm} \mathrm{h}^{-1}\right)$ based on linear regression using eq. (15), for slope gradients $<25 \%$. An average value of $251 \mathrm{~mm} \mathrm{~h}^{-1}$ for slope gradients $>25 \%$ was used in the map.
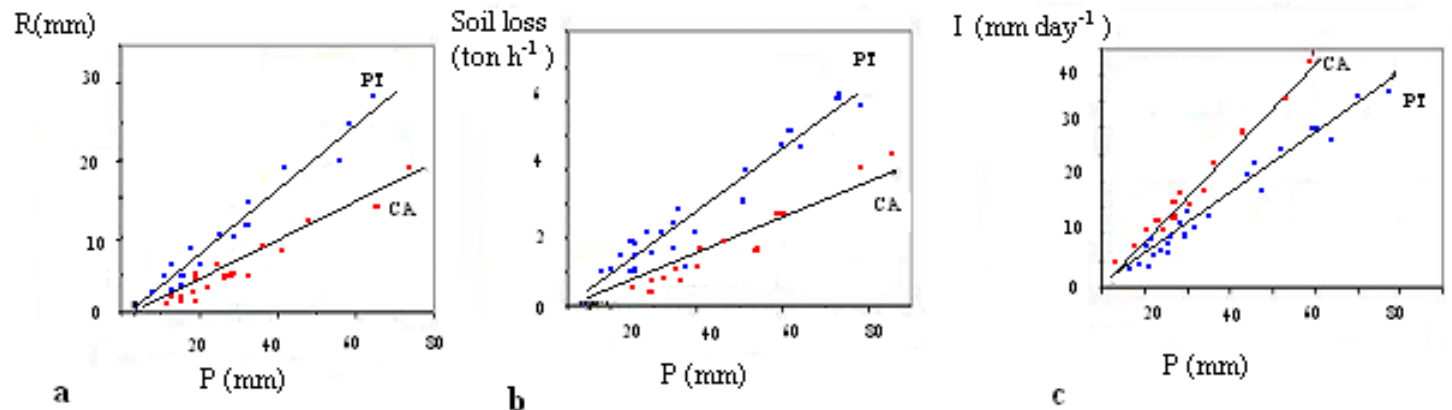

Figure 8. Contrasts between Plain Tillage (in blue) and Conservation Agriculture (in red) for the relations between daily rainfall (P) and (a) daily runoff (R), (b) soil loss, and (c) infiltrated water (I) as measured on the runoff plot. Every dot represents the average of measurements on 3 subplots. 

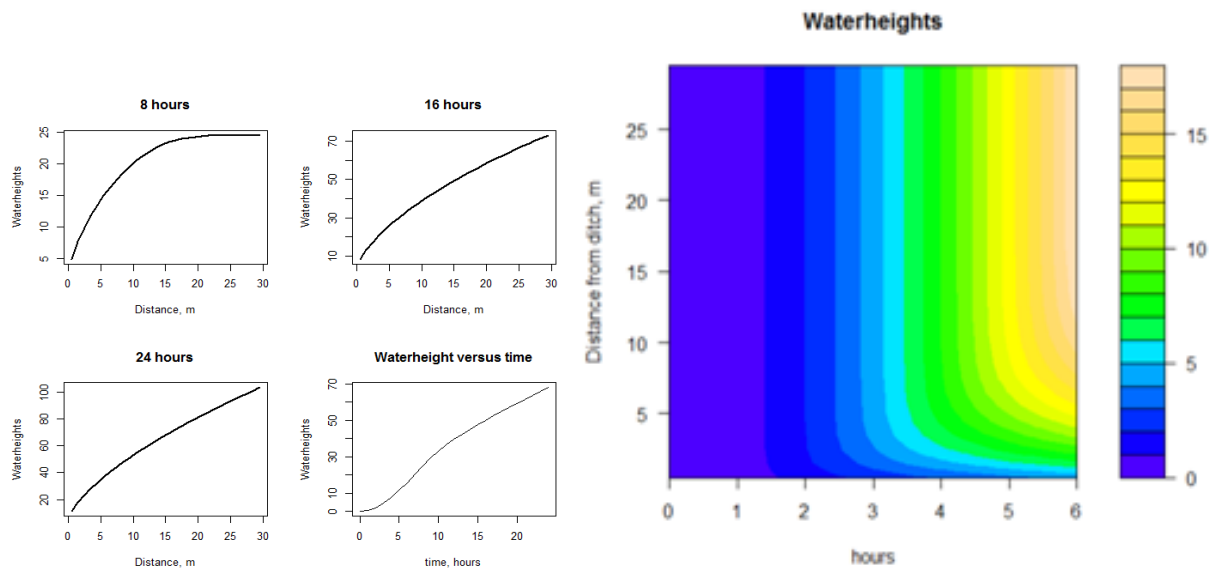

Figure 9. Ponding water heigth $(\mathrm{mm})$ on CA for runoff lengths $(\mathrm{m})$ and storm duration (hours).

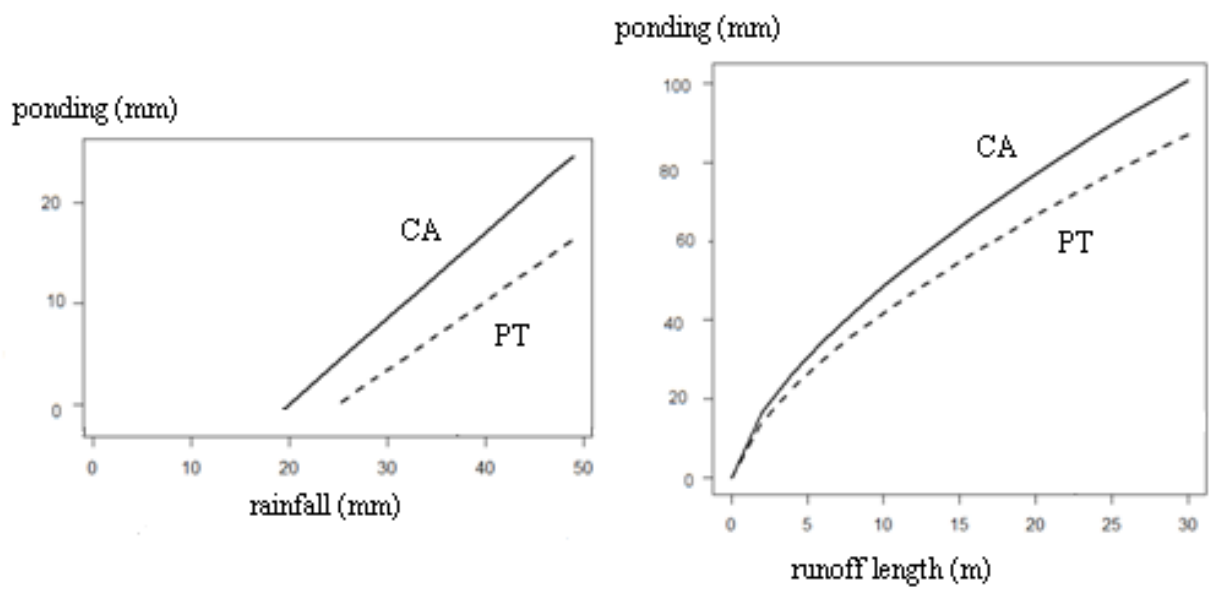

Figure 10. Modelled height of the ponding water $(\mathrm{mm})$ for different rainfall depths, and runoff lengths 


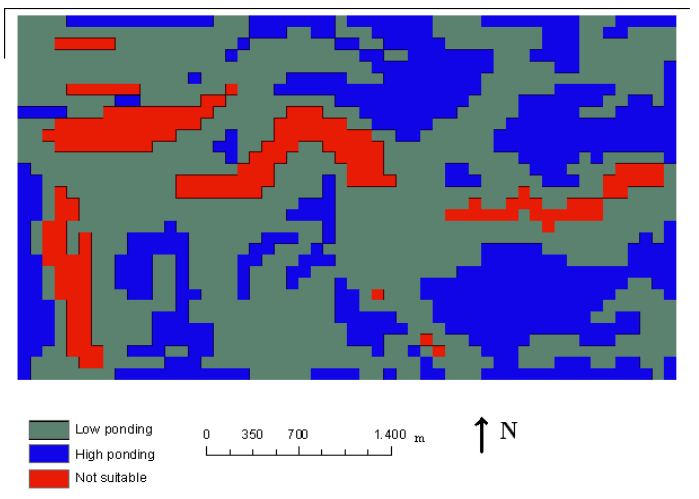

Figure 11. Ponding map, showing the $33 \%$ pixels most prone to ponding, assuming that land with field-saturated infiltration $<321 \mathrm{~mm} \mathrm{~h}-1$ is prone to ponding. Leptosols with slope gradients $>25 \%$ and which are generally not suitable for agriculture, are not involved in this analysis.
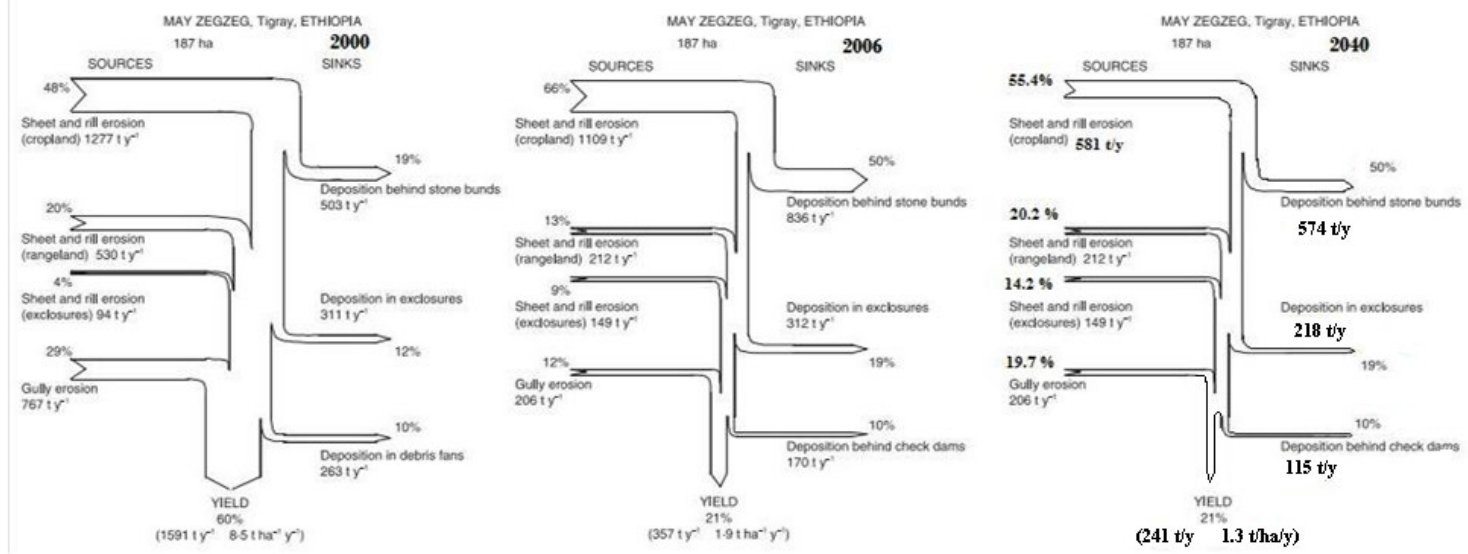

Figure 12. Sediment budgets of May Zeg-zeg of 2000 and 2006 (after Nyssen et al., 2009a) and recalculated budget for 2040 (full implementation of CA on all croplands). Arrow widths indicate intensity of mass transfers. 


\section{Tables}

Table 1. Soil organic carbon content (Walkley-Black method), as measured on mixed soil samples.

\begin{tabular}{lc}
\hline Mixed soil sample & $\%$ OC \\
\hline Regosols lower limestone area & 0.96 \\
Regosols Igrimulo limestone area & 1.35 \\
Regosols middle limestone area & 1.47 \\
Regosols upper limestone area & 1.77 \\
Regosols on basalt & 2.20 \\
Vertisols on basalt & 1.86 \\
Cambisols on basalt & 1.41 \\
\hline
\end{tabular}


Table 2. Texture of different soil types in MZZ catchment, as obtained with wet sieving technique (separating sand from silt and clay) and X-ray sedigraphy (separating clay from silt).

\begin{tabular}{|c|c|c|c|c|c|c|c|}
\hline Soil sample & $\begin{array}{l}\text { \% clay } \\
(<2 \mu \mathrm{m})\end{array}$ & $\begin{array}{c}\% \text { silt }(2- \\
63 \mu \mathrm{m})\end{array}$ & $\begin{array}{c}\% \text { sand } \\
(63-200 \\
\mu \mathrm{m})\end{array}$ & $\begin{array}{c}\text { Error } \\
\text { estimate }\end{array}$ & $\begin{array}{c}\text { Texture } \\
\text { (USDA } \\
\text { classification) }\end{array}$ & $\begin{array}{l}\text { Number } \\
\text { of } \\
\text { samples } \\
\text { mixed }\end{array}$ & $\begin{array}{c}\text { Average slope } \\
\text { gradient }(\%)\end{array}$ \\
\hline $\begin{array}{l}\text { Regosol upper } \\
\text { limestone area }\end{array}$ & 20.3 & 23.8 & 54.0 & $1.9 \%$ & $\begin{array}{l}\text { Sandy clay } \\
\text { loam }\end{array}$ & 5 & 13.6 \\
\hline $\begin{array}{l}\text { Regosol middle } \\
\text { limestone area }\end{array}$ & 30.1 & 29.7 & 38.8 & $1.4 \%$ & Clay loam & 5 & 5.2 \\
\hline $\begin{array}{l}\text { Regosol lower } \\
\text { limestone area }\end{array}$ & 4.7 & 27.0 & 67.0 & $1.3 \%$ & Sandy loam & 5 & 4.5 \\
\hline $\begin{array}{l}\text { Regosol Hechi } \\
\text { area }\end{array}$ & 10.5 & 26.3 & 62.3 & $1.1 \%$ & Sandy loam & 6 & 2.1 \\
\hline $\begin{array}{l}\text { Regosol on } \\
\text { basalt }\end{array}$ & 23.7 & 16.8 & 58.5 & $1.0 \%$ & $\begin{array}{l}\text { Sandy clay } \\
\text { loam }\end{array}$ & 5 & 4.1 \\
\hline $\begin{array}{l}\text { Cambisol on } \\
\text { basalt }\end{array}$ & 70.0 & 20.0 & 10.0 & $0.0 \%$ & Clay & 5 & 5.2 \\
\hline $\begin{array}{l}\text { Vertisol on } \\
\text { basalt }\end{array}$ & 75.0 & 20.0 & 5.0 & $0.0 \%$ & Clay & 5 & 3.4 \\
\hline
\end{tabular}

Table 3. Pearson product-moment coefficients $r$ of all continuous factors

\begin{tabular}{lcccc}
\hline & $\begin{array}{c}\text { Infiltration rate } \\
\left(\mathrm{mm} \mathrm{h}^{-1}\right)\end{array}$ & $\begin{array}{c}\text { Crop height } \\
(\mathrm{m})\end{array}$ & $\begin{array}{c}\text { Slope gradient } \\
(\%)\end{array}$ & $\begin{array}{c}\text { Elevation } \\
(\mathrm{m})\end{array}$ \\
\hline Infiltration rate $\left(\mathrm{mm} \mathrm{h}^{-1}\right)$ & +1.00 & +0.27 & +0.69 & +0.19 \\
Crop height $(\mathrm{m})$ & $\mathrm{x}$ & +1.00 & +0.14 & -0.24 \\
Slope gradient $(\%)$ & $\mathrm{x}$ & $\mathrm{x}$ & +1.00 & +0.17 \\
Elevation $(\mathrm{m})$ & $\mathrm{x}$ & $\mathrm{x}$ & $\mathrm{x}$ & +1.00 \\
\hline
\end{tabular}


Table 4. Comparison of Soil Organic Carbon content for paired CA and PT plots, as determined with Walkley-Black method. All samples were mixed and consist of several subsamples.

Site name $\quad \%$ SOC

CA PT difference

Hechi $\quad 0.92 \quad 0.89+0.03$

Limestone $\quad 1.87 \quad 1.35+0.52$

Basalt $\quad 1.43 \quad 1.41+0.02$

Table 5. Recalculated Curve Numbers for CA, indicating the strong impact of CA on runoff.

\begin{tabular}{lll}
\hline Cultivation type & CN PT & CN CA
\end{tabular}

Cropland A (free grazing, no $\quad 79.9 \quad 76.9$

stone bunds)

Cropland B (free grazing, stone $\quad 79.4 \quad 76.5$

bunds of medium quality)

Cropland C (free grazing, good

$78.5 \quad 75.6$

stone bunds)

Cropland D ('zero' grazing, no

$\begin{array}{ll}78.7 & 75.8\end{array}$

stone bunds)

Cropland E ('zero' grazing, stone $\quad 78.2 \quad 75.3$

bunds of medium quality)

Cropland F ('zero' grazing, good $\quad 77.3 \quad 74.4$

stone bunds) 
Table 6. Curve Numbers $(\mathrm{CN})$ and area of all land types in the catchment (after Nyssen et al., 2010) and calculation for a hypothetical situation with full implementation of CA in 2040 on all farmlands of the whole catchment (assuming no land use changes after 2006 and with the same $\mathrm{CN}$ values for all but cropland). Cropland types as indicated in Table 5.

\begin{tabular}{|c|c|c|c|c|c|c|c|c|c|}
\hline \multirow[t]{2}{*}{ Land use } & \multicolumn{3}{|c|}{2000} & \multicolumn{3}{|c|}{2006} & \multicolumn{3}{|c|}{2040} \\
\hline & $\mathrm{CN}$ & Area & $\%$ & $\mathrm{CN}$ & Area & $\%$ & $\mathrm{CN}$ & Area & $\%$ \\
\hline Fallow land & 89.5 & 1.6 & 1.1 & 89.5 & 0.1 & 0.1 & 89.5 & 0.1 & 0.1 \\
\hline Cropland A & 79.9 & 25.7 & 17.8 & 79.9 & 3.0 & 2.4 & 76.5 & 3.0 & 2.4 \\
\hline Cropland B & 79.4 & 63.3 & 43.9 & 79.4 & 35.0 & 27.4 & 75.6 & 35.0 & 27.4 \\
\hline Cropland C & 78.5 & 11.1 & 7.7 & 78.5 & 18.1 & 14.2 & 75.8 & 18.1 & 14.2 \\
\hline Cropland D & 78.7 & 0.0 & 0.0 & 78.7 & 1.5 & 1.1 & 75.3 & 1.5 & 1.1 \\
\hline Cropland E & 78.2 & 0.0 & 0.0 & 78.2 & 4.9 & 3.9 & 74.4 & 4.9 & 3.9 \\
\hline Cropland F & 77.3 & 0.0 & 0.0 & 77.3 & 22.7 & 17.8 & 76.9 & 22.7 & 17.8 \\
\hline $\begin{array}{l}\text { Exclosure (no stone } \\
\text { bunds) }\end{array}$ & 67.3 & 24.4 & 16.9 & 45.7 & 0.0 & 0.0 & 45.7 & 0.0 & 0.0 \\
\hline $\begin{array}{l}\text { Exclosure (medium } \\
\text { quality stone bunds) }\end{array}$ & 66.6 & 0.0 & 0.0 & 45.5 & 5.0 & 3.9 & 45.5 & 5.0 & 3.9 \\
\hline $\begin{array}{l}\text { Exclosure (good } \\
\text { stone bunds) }\end{array}$ & 65.6 & 0.0 & 0.0 & 45.2 & 29.5 & 23.1 & 45.2 & 29.5 & 23.1 \\
\hline Grassland & 45.7 & 0.9 & 0.6 & 45.7 & 0.8 & 0.6 & 45.7 & 0.8 & 0.6 \\
\hline $\begin{array}{l}\text { Grassland with } \\
\text { dense runoff } \\
\text { collector trenches }\end{array}$ & 45.2 & 0.0 & 0.0 & 45.2 & 3.0 & 2.3 & 45.2 & 3.0 & 2.3 \\
\hline Rangeland & 89.5 & 17.1 & 11.9 & 89.5 & 4.0 & 3.2 & 89.5 & 4.0 & 3.2 \\
\hline $\begin{array}{l}\text { Land involved in } \\
\mathrm{CN} \text { calculation }\end{array}$ & $\mathrm{x}$ & 144.1 & 100.0 & $\mathrm{x}$ & 127.5 & 100.0 & $\mathrm{x}$ & 127.5 & 100.0 \\
\hline $\begin{array}{l}\text { Land draining to } \\
\text { sink areas }\end{array}$ & NA & 19.8 & $\mathrm{x}$ & NA & 37.1 & $\mathrm{x}$ & NA & 37.1 & $\mathrm{x}$ \\
\hline TOTAL & $\mathrm{x}$ & 163.9 & 100.0 & $\mathrm{x}$ & 164.7 & 100.0 & $\mathrm{x}$ & 164.7 & 100.0 \\
\hline $\begin{array}{l}\text { Catchment weighted } \\
\text { average } \mathrm{CN}\end{array}$ & 78.5 & & & 68.9 & & & 67.2 & & \\
\hline
\end{tabular}


Table 7. Calculation of the P management factor in the RUSLE equation for CA in MZZ area

\begin{tabular}{|c|c|c|c|c|c|c|c|c|c|c|c|}
\hline & $\begin{array}{l}\text { Soil } \\
\text { loss }\end{array}$ & $\begin{array}{l}\text { Soil } \\
\text { loss }\end{array}$ & $\mathrm{R}$ & $\mathrm{K}(\mathrm{PT})$ & $\begin{array}{c}\mathrm{K} \\
(\mathrm{CA})\end{array}$ & S & $\mathrm{L}$ & $\mathrm{C}$ & $\begin{array}{c}\mathrm{P} \\
(\mathrm{PT})\end{array}$ & $\begin{array}{c}\mathrm{P} \\
(\mathrm{CA})\end{array}$ & $\begin{array}{l}\mathrm{Pm} \\
(\mathrm{CA})\end{array}$ \\
\hline & $\mathrm{PT}$ & $\mathrm{CA}$ & & & & & & & & & \\
\hline 2005 & 23.1 & 13.2 & 4166 & 0.0534 & 0.0482 & 0.7035 & 0.823 & 0.21 & 0.51 & 0.30 & 0.33 \\
\hline 2008 & 24.3 & 11.2 & 3473 & 0.0534 & 0.0482 & 0.7035 & 0.823 & 0.21 & 1.02 & 0.48 & 0.54 \\
\hline 2010 & 24.1 & 12.2 & 4353 & 0.0534 & 0.0482 & 0.7035 & 0.823 & 0.21 & 0.81 & 0.42 & 0.47 \\
\hline average & 23.6 & 12 & 3997 & 0.0534 & 0.0482 & 0.7035 & 0.823 & 0.21 & 0.88 & 0.40 & 0.45 \\
\hline $\begin{array}{l}\text { Soil loss } \\
\text { values of } \\
\text { PT (since } \\
\text { and very } \\
\text { permeabil } \\
\text { calculated } \\
\text { together) }\end{array}$ & $\begin{array}{l}\left.\mathrm{ha}^{-1}\right) \mathrm{m} \\
66 \mathrm{~mm} \\
\text { values o } \\
\text { ine sanc } \\
\text { ty parar } \\
\text { with eq }\end{array}$ & $\begin{array}{l}\text { asured } \\
2005) \text {, } \\
\text { OC are } \\
44), \mathrm{OI} \\
\text { eter } 1 \\
\text { (6); L }\end{array}$ & $\begin{array}{l}\text { differen } \\
\text { ( }(\mathrm{OC} x \\
\text { very fa } \\
\text { calculate }\end{array}$ & $\begin{array}{l}\text { 2008) and } \\
\text { with text } \\
1.724 \text { ) for } \\
\text { ) and sto } \\
\text { with eq. }\end{array}$ & $\begin{array}{l}\text { plot (avera } \\
706 \mathrm{~mm}(2 \\
\text { re paramet } \\
\text { CA } 3.03 \% \\
\text { iness facto } \\
\text { 7); crop fac }\end{array}$ & $\begin{array}{l}\text { ge of } 3 \text { sub } \\
2010 \text { ); erodi } \\
\text { er M } 2728 \\
\text { and for PT } \\
\text { or } 22 \% \text { (as } \\
\text { ctor C for }\end{array}$ & $\begin{array}{l}\text { plots); er } \\
\text { bility } \mathrm{K} \\
\text { (for Cam } \\
2.69 \% \text {, } \\
\text { derived } \\
\text { heat anc }\end{array}$ & $\begin{array}{l}\text { osivity } \\
\text { calculat } \\
\text { bisols o } \\
\text { structur } \\
\text { from I } \\
\text { hanfez }\end{array}$ & $\begin{array}{l}\text { calcula } \\
\text { d separe } \\
\text { basalt: } \\
\text { parame } \\
\text { yssen e } \\
\text { (wheat }\end{array}$ & $\begin{array}{l}\text { ted with } \\
\text { tely for } \\
\text { \%clay } 3 \\
\text { ter } 2 \text { (sta } \\
\text { al., } 20 \\
\text { ind barle }\end{array}$ & $\begin{array}{l}\text { rainfall } \\
\text { CA and } \\
\text {; \%silt } \\
\text { ndard), } \\
\text { 9a); S } \\
\text { y sown }\end{array}$ \\
\hline
\end{tabular}

Table 8. Six scenarios, depending on climate situation and land management applied. Catchment management accounts for non-grazing policy, stone bunds, exclosures and check dams.

\begin{tabular}{l|lll}
\hline & $\begin{array}{l}\text { Plain tillage few } \\
\text { conservation } \\
\text { measures }\end{array}$ & $\begin{array}{l}\text { Plain tillage with } \\
\text { catchment } \\
\text { management }\end{array}$ & $\begin{array}{l}\text { Catchment } \\
\text { management with } \\
\text { Conservation } \\
\text { Agriculture }\end{array}$ \\
\hline $\begin{array}{l}\text { Current average } \\
\text { precipitation } \\
\begin{array}{l}\text { Increase in precipitation } \\
\text { (IPCC projection A1FI for } \\
2041-2050)\end{array}\end{array}$ & Scenario II & Scenario IV & Scenario VI \\
\hline
\end{tabular}




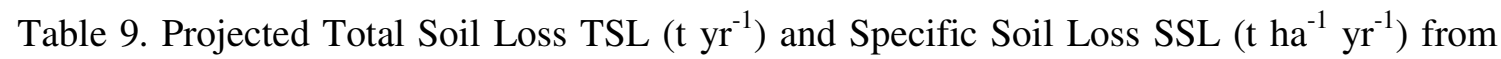
croplands in May Zeg-zeg catchment for the scenarios of 2006 without CA and 2040 with maximal implementation of CA.

\begin{tabular}{|c|c|c|c|c|c|}
\hline \multirow[t]{2}{*}{ Year } & $\begin{array}{c}2006 \text { and } \\
2040\end{array}$ & $\begin{array}{c}2006 \text { (Scenario } \\
\text { III) }\end{array}$ & $\begin{array}{c}2006 \\
\text { (Scenario III) }\end{array}$ & $\begin{array}{c}2040 \\
(\text { Scenario V) }\end{array}$ & $\begin{array}{c}2040 \\
(\text { Scenario V) }\end{array}$ \\
\hline & Area (ha) & $\begin{array}{c}\mathrm{SSL}\left(\mathrm{t} \mathrm{ha}^{-1} \mathrm{yr}^{-}\right. \\
1)\end{array}$ & 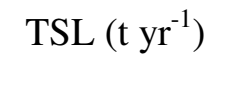 & $\begin{array}{c}\text { SSL ( } \mathrm{t} \mathrm{ha}^{-1} \\
\left.\mathrm{yr}^{-1}\right)\end{array}$ & 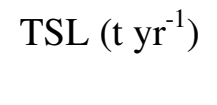 \\
\hline $\begin{array}{l}\text { crop land } \\
\text { free grazing }\end{array}$ & 62 & 9.9 & 613.8 & 5.2 & 320.9 \\
\hline $\begin{array}{l}\text { crop land } \\
\text { non grazing }\end{array}$ & 63 & 7.9 & 497.7 & 4.1 & 260.2 \\
\hline total & 125 & 8.9 & 1112.5 & 4.6 & 581.0 \\
\hline
\end{tabular}

Table 10. Soil loss estimations at experimental plot scale under different scenarios (climate change $\mathrm{x}$ land management)

\begin{tabular}{|c|c|c|c|c|c|c|c|}
\hline & $\mathrm{R}$ & $\mathrm{K}$ & $\mathrm{S}$ & $\mathrm{L}$ & $\mathrm{C}$ & $\mathrm{P}$ & Soil loss $\left(\mathrm{t} \mathrm{ha}^{-1} \mathrm{yr}^{-1}\right)$ \\
\hline Scenario I and III & 3997 & 0.0534 & 0.7035 & 0.823 & 0.21 & 0.88 & 22.8 \\
\hline Scenario II and IV & 5288 & 0.0534 & 0.7035 & 0.823 & 0.21 & 0.88 & 30.2 \\
\hline Scenario V & 3997 & 0.0482 & 0.7035 & 0.823 & 0.21 & 0.40 & 9.4 \\
\hline Scenario VI & 5288 & 0.0482 & 0.7035 & 0.823 & 0.21 & 0.40 & 12.4 \\
\hline
\end{tabular}


Table 11. Effects of the six scenarios on soil-water behavior in MZZ catchment (= indicates no change; $\uparrow$ indicates increase; blank is not estimated).

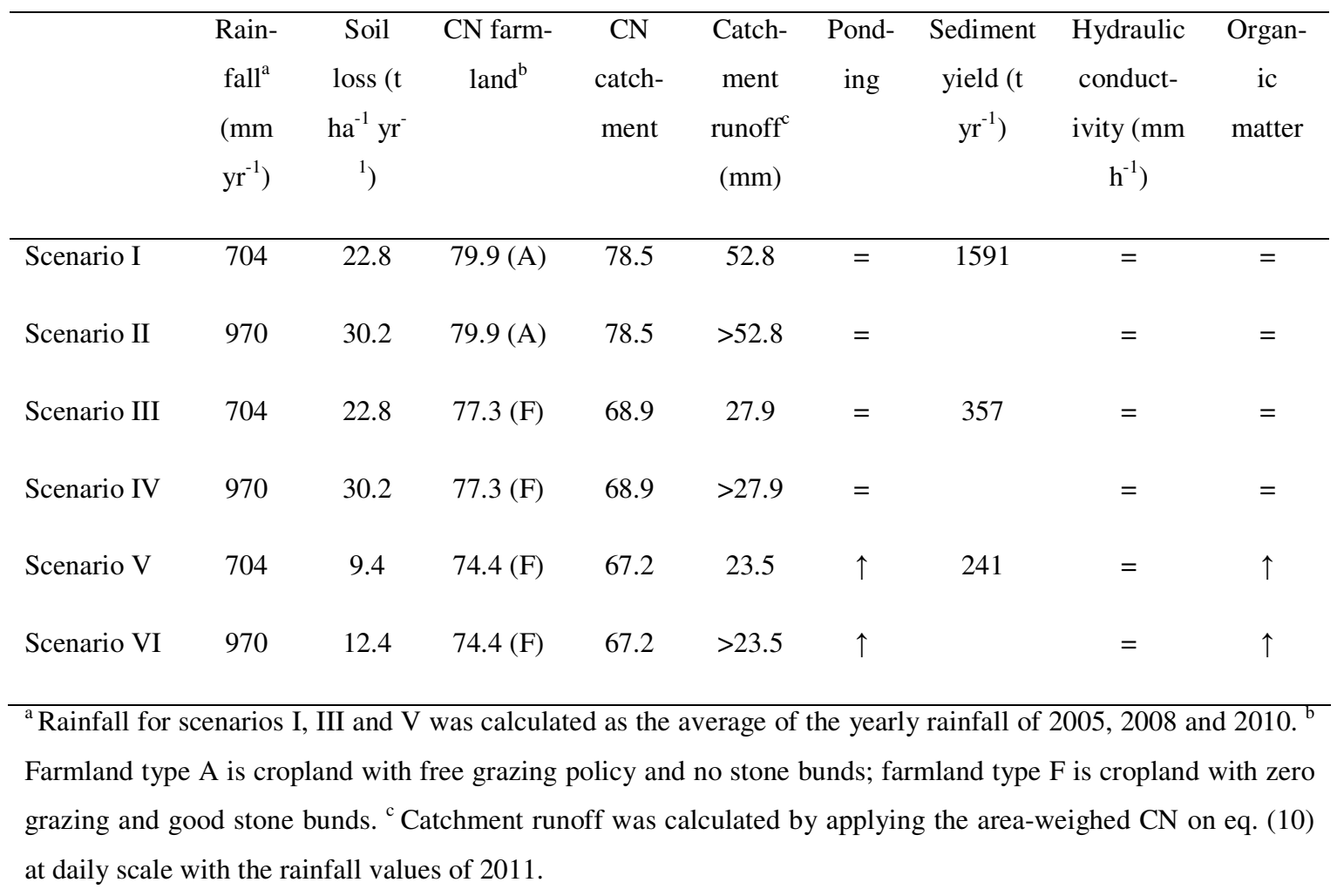

